SNS 101060200-TRO001-R0O

Summary of Mercury Compatibility Issues

for the Spallation

Neutron Source Target

Containment and Ancillary

Equipment

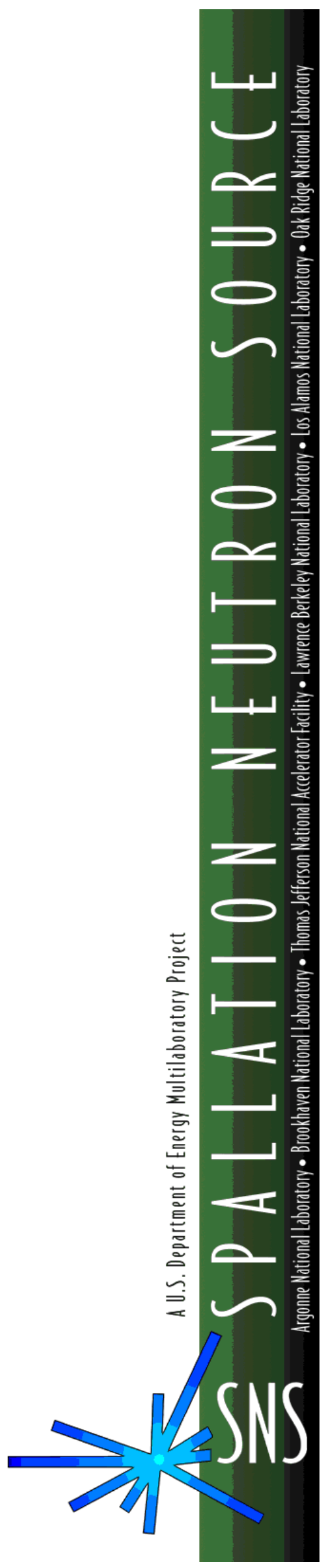

December 2002 



\section{SUMMARY OF MERCURY COMPATIBILITY ISSUES FOR THE SPALLATION NEUTRON SOURCE TARGET CONTAINMENT AND ANCILLARY EQUIPMENT}

December 2002

S. J. Pawel 


\section{DOCUMENT AVAILABILITY}

Reports produced after January 1, 1996, are generally available free via the U.S. Department of Energy (DOE) Information Bridge.

Web site http://www.osti.gov/bridge

Reports produced before January 1, 1996, may be purchased by members of the public from the following source.

National Technical Information Service

5285 Port Royal Road

Springfield, VA 22161

Telephone 703-605-6000 (1-800-553-6847)

TDD 703-487-4639

Fax 703-605-6900

E-mail info@ntis.fedworld.gov

Web site http://www.ntis.gov/support/ordernowabout.htm

Reports are available to DOE employees, DOE contractors, Energy Technology Data Exchange (ETDE) representatives, and International Nuclear Information System (INIS)

representatives from the following source.

Office of Scientific and Technical Information

P.O. Box 62

Oak Ridge, TN 37831

Telephone 865-576-8401

Fax 865-576-5728

E-mail reports@adonis.osti.gov

Web site http://www.osti.gov/contact.html

This report was prepared as an account of work sponsored by an agency of the United States Government. Neither the United States Government nor any agency thereof, nor any of their employees, makes any warranty, express or implied, or assumes any legal liability or responsibility for the accuracy, completeness, or usefulness of any information, apparatus, product, or process disclosed, or represents that its use would not infringe privately owned rights. Reference herein to any specific commercial product, process, or service by trade name, trademark, manufacturer, or otherwise, does not necessarily constitute or imply its endorsement, recommendation, or favoring by the United States Government or any agency thereof. The views and opinions of authors expressed herein do not necessarily state or reflect those of the United States Government or any agency thereof. 
Metals and Ceramics Division

\title{
SUMMARY OF MERCURY COMPATIBILITY ISSUES FOR THE SPALLATION NEUTRON SOURCE TARGET CONTAINMENT AND ANCILLARY EQUIPMENT
}

\author{
S. J. Pawel
}

Date Published: December 2002

Prepared for the

U.S. Department of Energy

Spallation Neutron Source

Prepared by the

OAK RIDGE NATIONAL LABORATORY

Oak Ridge, Tennessee 37831-6285

operated by

UT-Battelle, LLC

for the

U.S. DEPARTMENT OF ENERGY

Under contract DE-AC05-000R22725 



\section{CONTENTS}

Page

LIST OF FIGURES $\ldots \ldots \ldots \ldots \ldots \ldots \ldots \ldots \ldots \ldots \ldots \ldots \ldots \ldots \ldots$

LIST OF TABLES $\ldots \ldots \ldots \ldots \ldots \ldots \ldots \ldots \ldots \ldots \ldots \ldots \ldots \ldots \ldots \ldots \ldots \ldots$

EXECUTIVE SUMMARY $\ldots \ldots \ldots \ldots \ldots \ldots \ldots \ldots \ldots \ldots \ldots \ldots \ldots \ldots \ldots$

1. INTRODUCTION $\ldots \ldots \ldots \ldots \ldots \ldots \ldots \ldots \ldots \ldots \ldots \ldots \ldots \ldots \ldots \ldots \ldots \ldots$

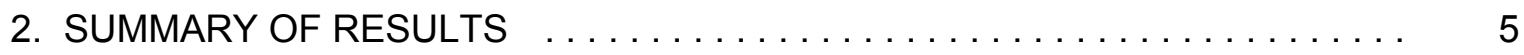

2.1 GENERAL DISSOLUTION AND THERMAL GRADIENT

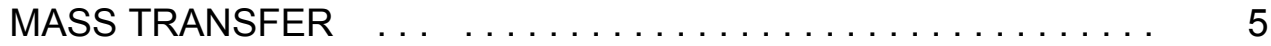

2.1.1 Thermal Convection Loops $\ldots \ldots \ldots \ldots \ldots \ldots \ldots \ldots \ldots$

2.1.2 Bench-Top Compatibility Tests ............... 14

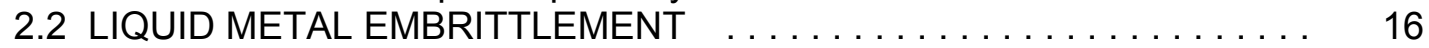

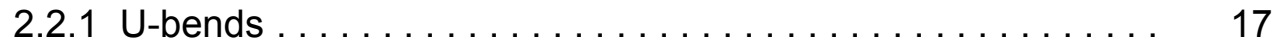

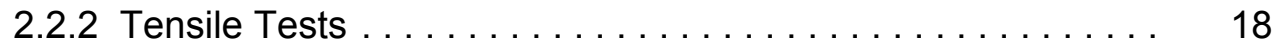

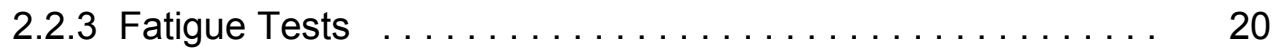

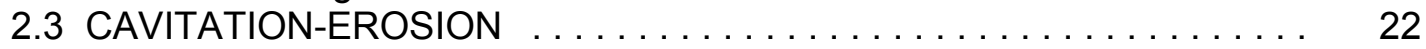

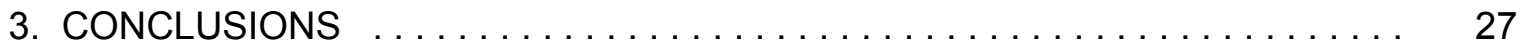

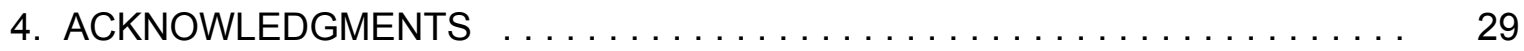

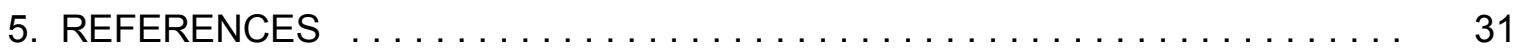





\section{LIST OF FIGURES}

Figure

Page

1. Schematic of the thermal convection loop design. The distance between thermocouple wells on each vertical section is about $70 \mathrm{~cm}$, and the vertical sections are separated by about $45 \mathrm{~cm}$. Inside diameter of the

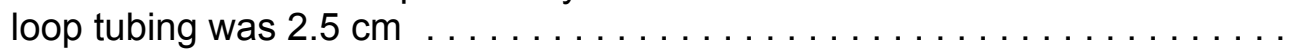

2. As-polished cross-section of unexposed 316L stainless steel coupon showing slight surface roughness in the as-machined condition $\ldots \ldots \ldots$

3. As-polished cross-section of $316 \mathrm{~L}$ coupon exposed $5000 \mathrm{~h}$ at $305^{\circ} \mathrm{C}$ in $\mathrm{Hg}$. Top photo is optical microscopy; bottom photo is higher magnification backscattered electron image. Light colored spots in the porous layer in bottom photo represent residual mercury $\ldots \ldots \ldots \ldots \ldots \ldots \ldots \ldots$

4. Representative microprobe data from the annealed 316 specimen from the top of the hot leg $\left(305^{\circ} \mathrm{C}\right)$ in the $\mathrm{Hg} \mathrm{TCL}$. Note that the peak associated with $\mathrm{Ni}$ is absent from the scan on the corroded material and the peaks associated with $\mathrm{Cr}$ are significantly reduced. The centers of the two measurement points - marked by " $\mathrm{x}$ " - are separated by $1.5 \mu \mathrm{m} \ldots \ldots \ldots$.

5. Compatibility chart for liquid mercury with a variety of materials.

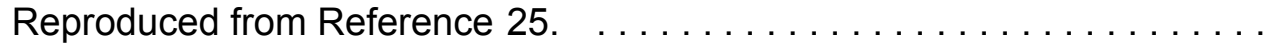

6. Schematic of the apparatus for mechanical testing of specimens

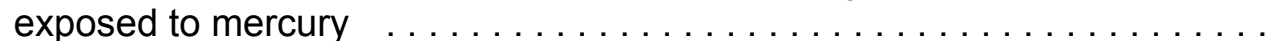

7. Summary of mechanical test data for $316 \mathrm{~L}$ stainless steel in the millannealed (MA), sensitizing heat treatment $\left(2 \mathrm{~h}\right.$ at $\left.650^{\circ} \mathrm{C}\right)$, and as-welded conditions in three different environments at room temperature $\ldots \ldots \ldots$.

8. Fracture surface of $316 \mathrm{LN}$ fatigue specimen tested in air at room temperature $(287 \mathrm{MPa}, 4935$ cycles to failure. Both photos are from

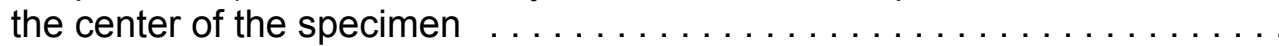

9. Fracture surface of $316 \mathrm{LN}$ fatigue specimen tested in $\mathrm{Hg}$ at room temperature (287 MPa, 2572 cycles to failure. Both photos are from

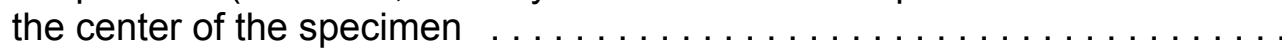

10. Specimen weight loss vs. exposure time for vibratory horn testing ( $25 \mu \mathrm{m}$ peak-to-peak displacement amplitude, $20 \mathrm{kHz}$ frequency, $25^{\circ} \mathrm{C}$ ) in $\mathrm{Hg}$. The trend lines are included for ease of presentation . . . . .

11. Scanning electron micrographs of the surface of annealed 316LN after sonication ( $25 \mu \mathrm{m}$ peak-to-peak displacement amplitude, 20 $\mathrm{kHz}$ frequency, $25^{\circ} \mathrm{C}$ ) for $150 \mathrm{~min}$ in $\mathrm{Hg}$. Photograph at right shows a higher magnification view of one of the large pits in the photograph at left 
12. Scanning electron micrograph of the surface of $50 \%$ cold-worked $316 \mathrm{LN}$ after sonication ( $25 \mu \mathrm{m}$ peak-to-peak displacement amplitude, $20 \mathrm{kHz}$ frequency, $25^{\circ} \mathrm{C}$ ) for $180 \mathrm{~min}$ in $\mathrm{Hg}$. This photograph is not particularly representative in that the entire specimen surface exhibited only 2-3 such indications

13. Annealed $316 \mathrm{LN}$ specimen receiving kolsterizing treatment and exposed to sonication ( $25 \mu \mathrm{m}$ peak-to-peak displacement amplitude, $20 \mathrm{kHz}$ frequency, $25^{\circ} \mathrm{C}$ ) for $60 \mathrm{~min}$ in $\mathrm{Hg}$ 


\section{LIST OF TABLES}

$\begin{array}{lll}\text { Table } & \text { Page }\end{array}$

1. General summary data for Loops 1 and $2 \ldots \ldots \ldots \ldots \ldots \ldots$

2. General summary data for Loops 3 and $4 \ldots \ldots \ldots \ldots \ldots$

3. General summary data for Loops 5 and $6 \ldots \ldots \ldots \ldots \ldots \ldots \ldots$

4. General summary data for Loops 7 and $8 \ldots \ldots \ldots \ldots \ldots \ldots$

5. General summary data for Loop $9 \ldots \ldots \ldots \ldots \ldots \ldots \ldots \ldots$

6. General summary data for Loop $10 \ldots \ldots \ldots \ldots \ldots \ldots \ldots \ldots$

7. General summary data for Loop $11 \ldots \ldots \ldots \ldots \ldots \ldots \ldots \ldots \ldots$ 



\section{EXECUTIVE SUMMARY}

The purpose of this document is to summarize the primary results of the $\mathrm{Hg}$ compatibility research in support of the SNS target. In the absence of possible synergisms resulting from beam/irradiation effects, wetting of $316 \mathrm{~L} / 316 \mathrm{LN}$ stainless steel under SNS conditions by the $\mathrm{Hg}$ target is expected to be very limited. As a result, significant interactions such as dissolution, mass transfer, and embrittlement affecting general compatibility are not anticipated. A wide range of experiments on $316 \mathrm{~L} / 316 \mathrm{LN}$ stainless steel, including thermal convection and pumped loops, confirmed low corrosion/penetration rates in $\mathrm{Hg}$ up to $305^{\circ} \mathrm{C}$ and little or no wetting or mass transfer below about $250^{\circ} \mathrm{C}$. A variety of standard mechanical tests comparing behavior of $316 \mathrm{~L}$ in air and $\mathrm{Hg}$ revealed limited wetting and no degradation of mechanical properties such as reduced elongation or development of brittle fracture features. Preliminary fatigue tests indicated a negative effect (reduced cycles to failure and intergranular cracking) at very high loads for $316 \mathrm{LN}$, but little or no effect at more modest loading. Annealed $316 \mathrm{LN}$ was found to be somewhat susceptible to cavitation-erosion damage, but significant improvement was realized with a kolsterizing surface treatment or coldworking the material. Within the scope of these test conditions, no compatibility-limited operations were identified for type $316 \mathrm{~L} / 316 \mathrm{LN}$ stainless steel (and variations thereof) as the $\mathrm{Hg}$ target containment material. More limited compatibility data on other materials are also reported. 



\section{INTRODUCTION}

The Spallation Neutron Source (SNS) will generate neutrons through interaction of a pulsed $1.0 \mathrm{GeV}$ proton beam with a liquid mercury target. Type 316L/316LN austenitic stainless steel has been selected as the target containment material ${ }^{1}$ based on a favorable combination of several factors, including resistance to corrosion by $\mathrm{Hg}$, satisfactory retention of mechanical properties in a radiation environment, and the absence of a ductile-brittle transition temperature such as that found in ferritic stainless steels. The full scope of the SNS target materials research and development program is reviewed in references $2-3$, where the compatibility work is described in the overall context of the materials R\&D program.

A critical issue affecting the corrosion of materials by $\mathrm{Hg}$ is the relative degree of chemical wetting of the material surface. For the purposes of this discussion, chemical wetting is defined as sufficiently intimate interaction that chemical exchange at the atomic level is possible. In a macroscopic sense, chemical wetting is indicated by a low contact angle between the liquid and a solid substrate - that is, a thin film of liquid covers the surface rather than individual spheres, or "beads," of liquid resting with limited contact area on the surface. Further, chemical wetting is commonly indicated by significant adhesion of the liquid to the solid surface. Without chemical wetting, it is impossible for the liquid to degrade the solid through simple dissolution or any other reaction.

It is important to distinguish chemical wetting from thermal wetting. Various experiments in support of the SNS design showed that the thermal conductivity between $\mathrm{Hg}$ and stainless steel containment approached theoretically calculated values under a variety of circumstances in which macroscopic evidence of chemical wetting was absent. ${ }^{4}$ Similarly, it is expected that electrical conductivity between the $\mathrm{Hg}$ and stainless steel substrate can exist without chemical wetting. In fact, for the SNS, it is desirable to achieve good thermal wetting (meaning adequate heat transfer) in the absence of chemical wetting (no adverse chemical reactions between the $\mathrm{Hg}$ and the containment). Since chemical wetting is such a critical factor from a compatibility point of view, various discussions of wetting in the remainder of this document refer to chemical wetting.

Austenitic stainless steels have proven very resistant to wetting by $\mathrm{Hg}$. Perhaps the primary reason is the thin and tenacious chromium-rich oxide film that forms spontaneously on these alloys upon exposure to air. Without catalytic action (outside influence), these oxide films are expected to resist interaction with $\mathrm{Hg}$ indefinitely 
because the affinity of $\mathrm{Hg}$ for oxygen is much less than that of $\mathrm{Cr}$ and $\mathrm{Fe}$ (and to a lesser extent, $\mathrm{Ni}$ ), which are the main elements in passive film formation in austenitic stainless steels. In a simplistic view, the free energy of formation of $\mathrm{Cr}$ and Fe oxides have much lower values than mercury oxides - meaning they are much more thermodynamically stable - at modest temperatures. ${ }^{5}$ In a practical sense, this means that $\mathrm{Hg}$ cannot be expected to strip oxygen from passive films on stainless steel. However, if the oxide films can be fractured or otherwise compromised, the possibility of wetting exists.

Wilkinson ${ }^{6}$ found that wetting by $\mathrm{Hg}$ (as evidenced by the contact angle) was critically dependent on surface layer cleanliness as opposed to any bulk properties of the substrate. In particular, the presence of absorbed impurities was found to significantly alter apparent wettability. Wilkinson ${ }^{6}$ cited work indicating specimens of $\mathrm{Fe}, \mathrm{Ni}, \mathrm{Mo}, \mathrm{W}$, and $\mathrm{Ti}$ that were polished, degreased, and bombarded with argon ions under vacuum immediately prior to $\mathrm{Hg}$ drop placement on the "cleaned" surface showed similarly high contact angles (poor wetting) compared with surfaces for which little cleaning effort was expended. However, the contact angles decreased to zero (good wetting) when the argon ion bombardment was reinitiated after placement of the $\mathrm{Hg}$ drop on the specimen surface. The conclusion was that contamination of the surface, even incomplete monolayers of contamination, could develop quickly and wetting only occurred if the surface was completely free of oxide and other contaminants.

Lending some credibility to the inhibiting effect of residual oxide films is the observation that small additions of $\mathrm{Ti}$ and/or $\mathrm{Mg}$ to $\mathrm{Hg}$ have been shown to improve heat transfer between $\mathrm{Hg}$ and steel at relatively high temperatures. ${ }^{7}$ The mechanism by which this occurs has not been exhaustively studied, but it appears that $\mathrm{Ti}$ and $\mathrm{Mg}$ are capable of gettering oxygen from both $\mathrm{Hg}$ and the steel surface, thus eliminating hightemperature oxide films and enhancing wetting.

In preliminary compatibility studies for the SNS, ${ }^{8}$ a variety of simple bench-top $\mathrm{Hg}$ wetting experiments with various stainless alloys were attempted. Different types of mechanical abrasion and chemical cleaning were used in an attempt to develop chemical wetting on 304/316 stainless steels and other alloys, but wetting was inconsistent or nonexistent at/near room temperature. Although precise measurement of $\mathrm{Hg}$ and metal substrate temperatures was not attempted, the most reproducible wetting of austenitic stainless steel by $\mathrm{Hg}$ was achieved by raising the temperature to the range $225-275^{\circ} \mathrm{C}$, where beads of $\mathrm{Hg}$ (high contact angle) began to collapse and at least semi-adherently coat the stainless steel substrate. The apparent wetting was quickly (seconds to minutes) destroyed, however, by decreasing the temperature below that of the range 
identified above. This pattern of behavior was found to be consistently true in air, helium, and vacuum.

Literature on compatibility with $\mathrm{Hg}$ identified several experiments in which small additions of another liquid metal were made to $\mathrm{Hg}$ in an attempt to increase wetting/interaction. Among the possibilities considered in the preliminary compatibility experiments for SNS, Ga seemed to offer the most promise as an additive to $\mathrm{Hg}$ because of its reputation as an aggressive liquid metal that wets many materials in its own right, does not contaminate $\mathrm{Hg}$ in terms of neutronics or waste disposal, and critically, has some solubility in $\mathrm{Hg}$ even at room temperature. As a result, a variety of bench-top wetting experiments also were conducted with $\mathrm{Hg}$ containing up to 1000 wppm of $\mathrm{Ga}$. Initially, it was thought that the Ga additions encouraged wetting, but further study indicated only that a gallium oxide "scum" loosely adhering to test pieces was misinterpreted as evidence of wetting. ${ }^{9,10}$ Nevertheless, a few subsequent experiments included $\mathrm{Ga}$ additions to $\mathrm{Hg}$ to examine potential changes in wetting behavior.

In sum, these preliminary compatibility experiments indicated that the expected SNS operating temperatures (up to about $100-120^{\circ} \mathrm{C}$ ) $\mathrm{Hg}$ does not readily wet potential target containment materials such as 316L/316LN stainless steel. However, despite the relatively low operating temperatures, it was anticipated that wetting may be experienced/promoted in the actual SNS target via possible synergistic action resulting from some combination of the presence of thermal hot spots, radiation damage/segregation in the presence of $\mathrm{Hg}$, and the generation of fresh oxide-free surfaces that result from potential fatigue/thermal-shock loading conditions or cavitationerosion. Accordingly, to examine potential "worst case" compatibility, many experiments were performed at artificially higher temperatures to obtain wetting and exacerbate potential interaction between $\mathrm{Hg}$ and the test material.

Upon that background, the purpose of this document is to review the primary results of the research effort to examine potential compatibility issues for the SNS target container material (316L/316LN stainless steel). This document does not include all of the findings of the program, but highlights primary conclusions and makes reference to the many relevant papers containing full details. 



\section{SUMMARY OF RESULTS}

\subsection{GENERAL DISSOLUTION AND THERMAL GRADIENT MASS TRANSFER}

\subsubsection{Thermal Convection Loops}

Because the $\mathrm{Hg}$ in the target is expected to circulate between two relatively fixed temperatures, one potential compatibility issue for the target containment is thermal gradient mass transfer. In this form of corrosion, dissolution of the container material by a flowing liquid in relatively high temperature (high solubility) regions is accompanied by deposition of solute in relatively colder (low solubility) regions. ${ }^{11}$ As a result, dissolution of material in the high temperature region is not limited by system equilibrium and, therefore, corrosion can continue over time compared to ceasing when saturation is reached in an isothermal/stagnant system. In addition, in the cold regions, deposition of solute material has been known to block flow paths in liquid metal loops and can be the life-limiting issue for systems of this type. ${ }^{12}$

To examine the potential for thermal gradient mass transfer in the liquid mercury target system, screening tests were initially performed using a rocker apparatus ${ }^{8}$ to generate $\mathrm{Hg}$ flow and a temperature gradient. As the target R\&D program expanded, however, more sophisticated analysis was undertaken using thermal convection loops (TCLs), which were operated under a variety of conditions/durations. ${ }^{10,13-17}$ The basic $^{2}$ design, fabrication, and operation of the TCLs has been previously documented ${ }^{10,13-17}$ but, for the convenience of the reader, a schematic of a typical TCL is shown in Fig. 1. The heated vertical leg of the TCL (termed the hot leg) and the air-cooled vertical leg (termed the cold leg) contained chains of test specimens for post-test evaluation via visual and weight change assessment as well as light microscopy and scanning electron microscopy of test surfaces and cross-sections. In addition, the TCLs themselves were often sectioned for post-test examination of the internal surfaces. The TCLs were operated with a prototypic temperature gradient, nominally about $70^{\circ} \mathrm{C}$ with one loop at about $90^{\circ} \mathrm{C}$, but at hot leg temperatures up to about $305^{\circ} \mathrm{C}$ to encourage chemical wetting as previously discussed. 


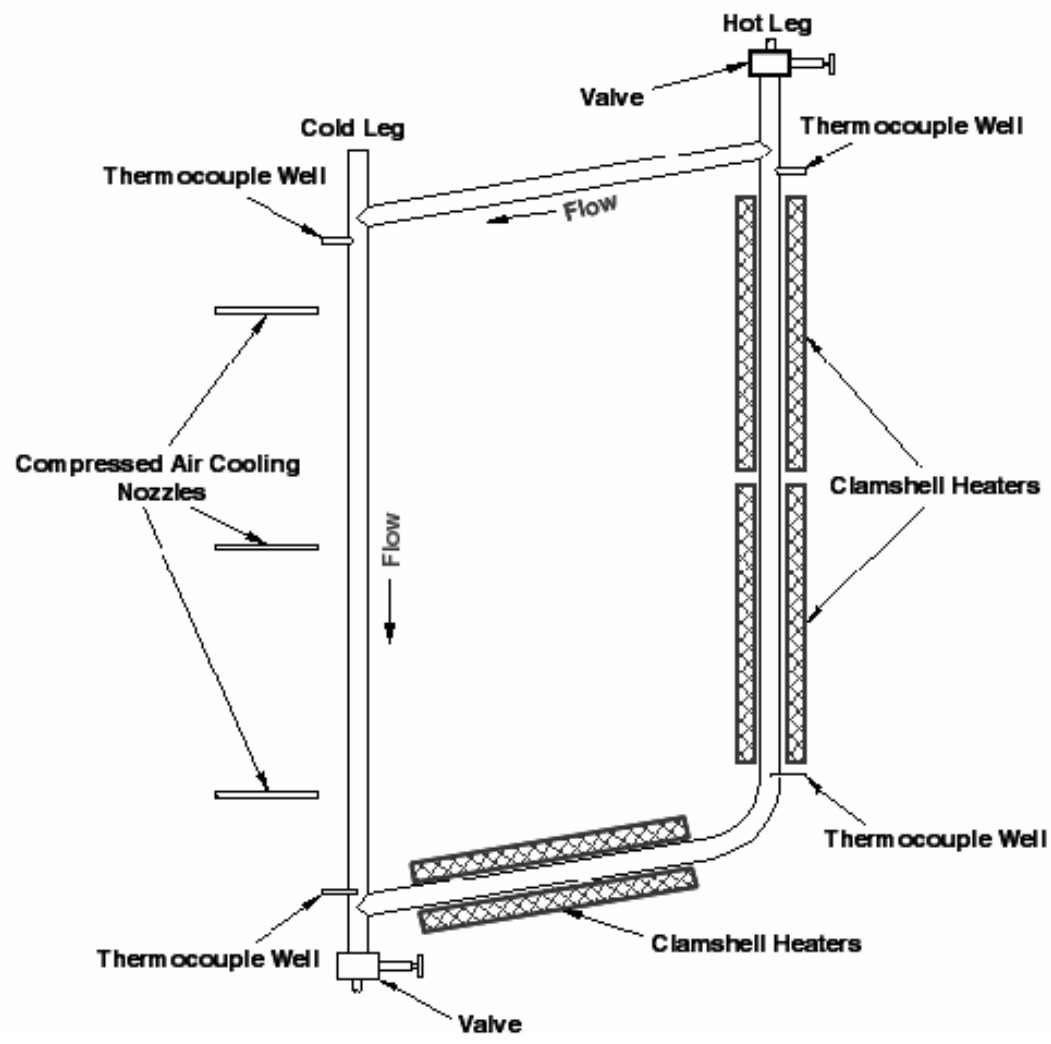

Fig. 2. Schematic of the thermal convection loop design.

The distance between thermocouple wells on each vertical section is about $70 \mathrm{~cm}$, and the vertical sections are separated by about $45 \mathrm{~cm}$. Inside diameter of the loop tubing was $2.5 \mathrm{~cm}$.

Among all the TCLs operated for this research program, the most significant result representing interaction between annealed $316 \mathrm{~L}$ stainless steel and $\mathrm{Hg}$ was observed in the initial experiment. In this particular TCL, ${ }^{13}$ the experiment was continued uninterrupted for almost $5000 \mathrm{~h}$ with annealed $316 \mathrm{~L}$ stainless steel coupons in both the hot leg $\left(305^{\circ} \mathrm{C}\right.$ peak) and cold leg $\left(242^{\circ} \mathrm{C}\right.$ minimum) with a mercury velocity of about $1.0-1.1 \mathrm{~m} / \mathrm{min}$ around the loop. Coupons exposed above about $255^{\circ} \mathrm{C}$ experienced weight loss and the development of a porous surface layer, each of which increased in magnitude/depth with increasing exposure temperature.

The coupon at the top of the hot leg $\left(305^{\circ} \mathrm{C}\right)$ experienced the maximum degradation in this experiment, exhibiting a porous surface layer penetrating an average of 9-10 $\mu \mathrm{m}$ after almost $5000 \mathrm{~h}$. Representative photomicrographs are shown in Figs. 2 and 3 , which compare the surface of unexposed and exposed specimens. 


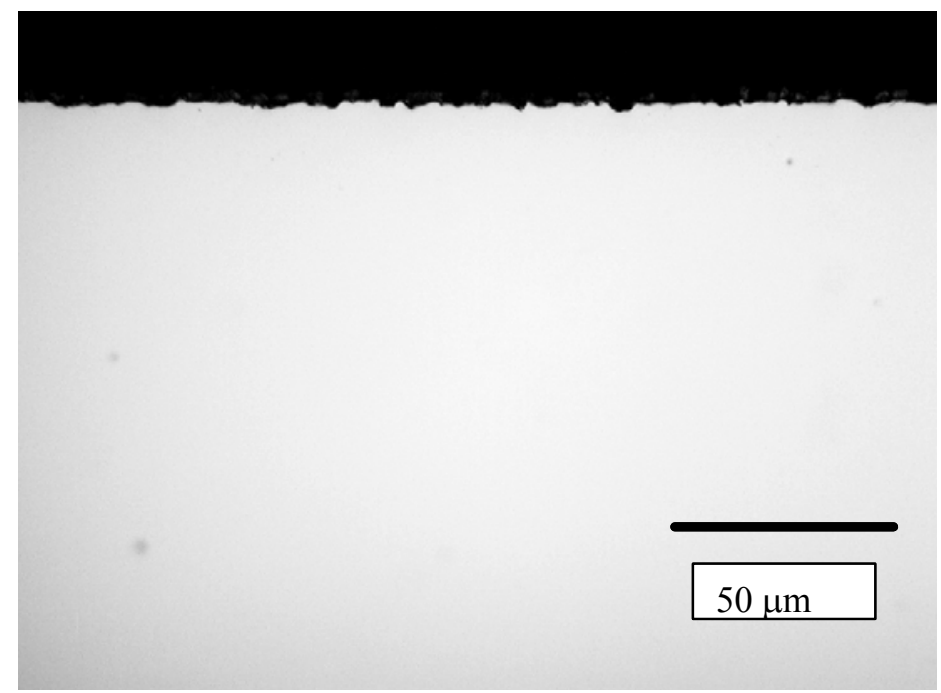

Fig. 3. As-polished cross-section of unexposed 316 L stainless steel coupon showing slight surface roughness in the as-machined condition.

Electron microprobe chemical analysis revealed that the porous surface of the coupons exposed above about $255^{\circ} \mathrm{C}$ was completely depleted of $\mathrm{Ni}$ and about $70 \%$ depleted of Cr. Further, the composition gradient at the interface between the depleted surface material and the adjacent bulk material is very steep. A representative microprobe scan is shown in Fig. 4 along with the area from which the microprobe data was collected. The scans compare elemental concentrations in material just barely on the liquid metal side of the reaction zone interface (surface side, "x" centered $6.8 \mu \mathrm{m}$ from the outer surface) with material just barely on the bulk side of this interface (" $x$ " centered $8.3 \mu \mathrm{m}$ from the outer surface). Similar analyses revealed the composition of the corroded/porous layer to be the same everywhere and the composition of the material on the bulk side of the interface matched that of the stainless steel far removed from the interface. The absence of composition gradients in/near the reaction zone and the analysis ${ }^{13}$ indicating a very low activation energy for the leaching suggested the rate controlling step for the process involved diffusion through the saturated liquid boundary layer adjacent to the corroding surface. Such a situation is expected to have results that are strongly dependent on velocity, e.g., mixing in the boundary layer, so for this reason - as well as the fact that the SNS was to operate at higher velocities than those experienced in the TCLs - some subsequent experiments examined the potential influence of velocity on compatibility. 


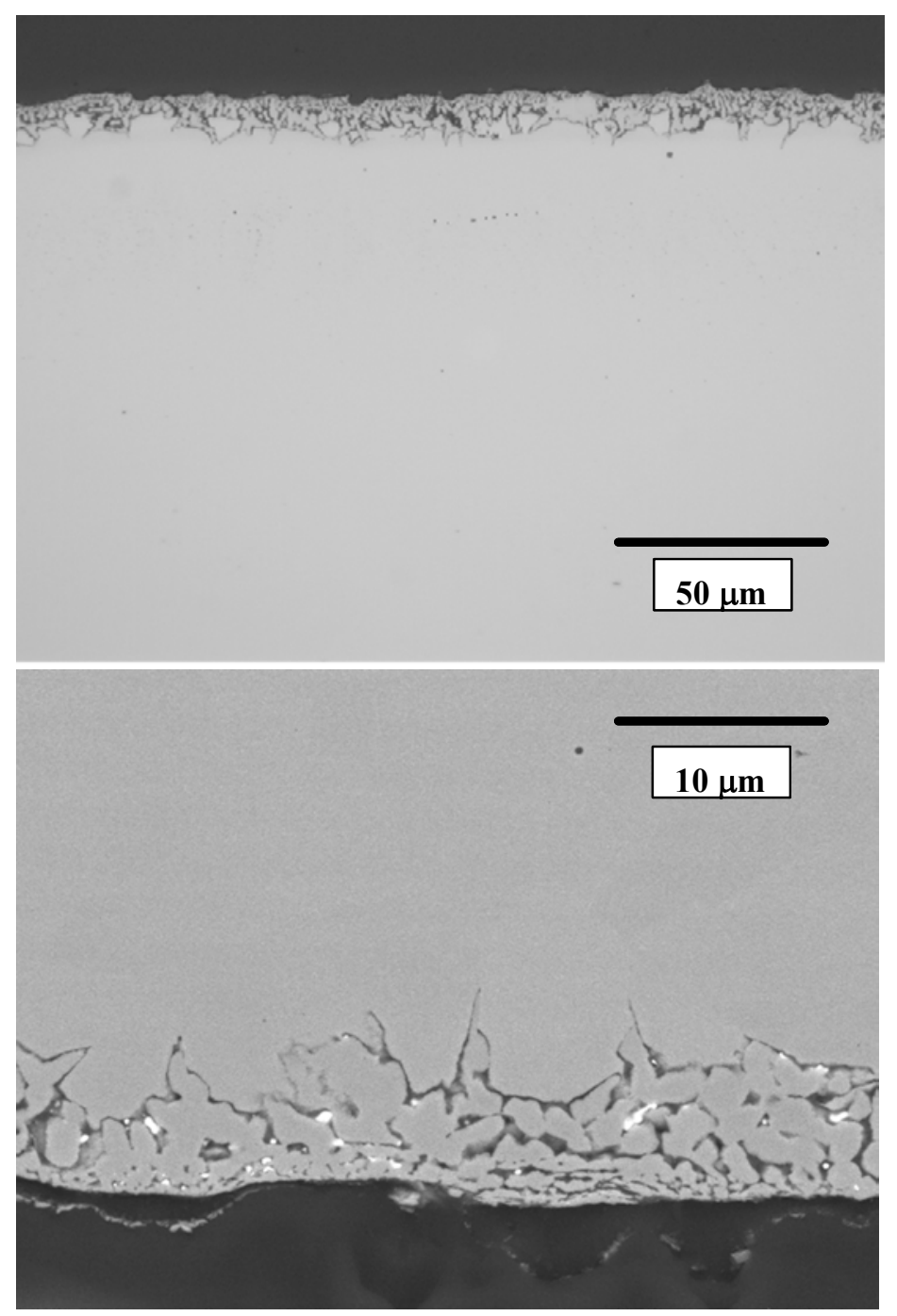

Fig. 4. As-polished cross-section of 316L coupon exposed $5000 \mathrm{~h}$ at $305^{\circ} \mathrm{C}$ in $\mathrm{Hg}$. Top photo is optical microscopy; bottom photo is higher magnification backscattered electron image. Light colored spots in the porous layer in bottom photo represent residual mercury. 


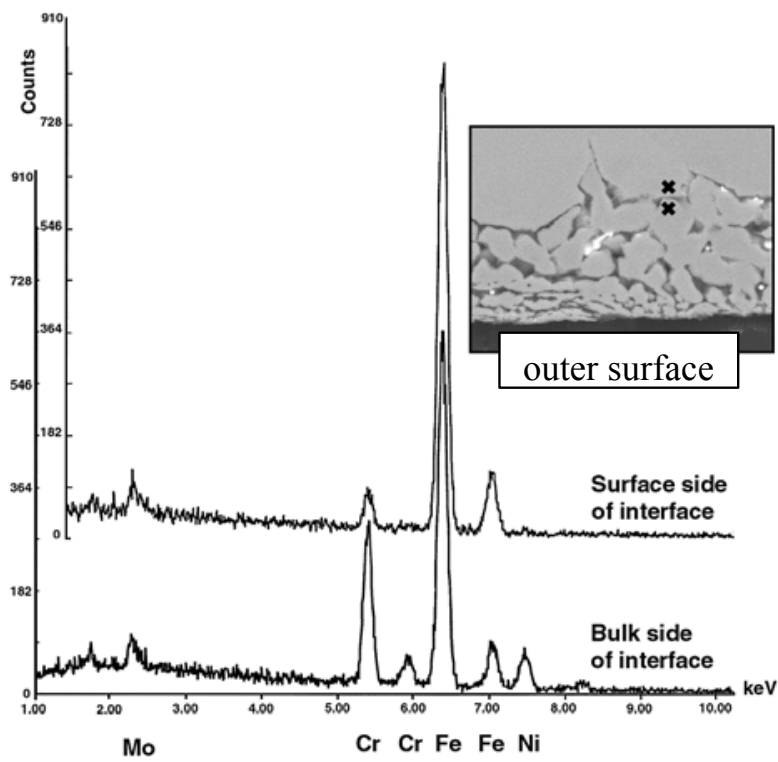

Fig. 5. Representative microprobe data from the annealed $316 \mathrm{~L}$ specimen from the top of the hot leg $\left(305^{\circ} \mathrm{C}\right)$ in the $\mathrm{Hg} \mathrm{TCL}$. Note that the peak associated with $\mathrm{Ni}$ is absent from the scan on the corroded material and the peaks associated with $\mathrm{Cr}$ are significantly reduced. The centers of the two measurement points - marked by " $x$ " - are separated by $1.5 \mu \mathrm{m}$.

The composition of the corroded region in coupons from other locations in the loop appears essentially independent of the exposure temperature and layer thickness.

However, no corroded layer at all was detected on coupons exposed at temperatures below about $255^{\circ} \mathrm{C}$.

Microstructural analysis revealed the surface layer to be quite porous approximately $23 \%,{ }^{13}$ on average - which results in significant reduction in strength of the affected material. The porosity is apparently interconnected in a complex labyrinth, as small beads of $\mathrm{Hg}$ were located deep in the porous structure in regions not directly connected to the surface in the plane of analysis.

Leaching of $\mathrm{Ni}$ from the surface of the specimen is consistent with the observation that, at least at somewhat higher temperature, the solubility of $\mathrm{Ni}$ in $\mathrm{Hg}$ is considerably higher than that of the other components of stainless steels. ${ }^{18}$ The solubility of $\mathrm{Cr}$ is somewhat lower in $\mathrm{Hg}$, but still significantly higher than that of $\mathrm{Fe}$. Leaching of $\mathrm{Ni}$ and $\mathrm{Cr}$ from the austenitic matrix leads not only to porosity but to chemical instability of the 
microstructure, causing a phase transformation of the affected material to ferrite. A practical consequence of this transformation is that the ferrite phase is magnetic (where annealed austenite is not), so the transformation can be detected non-destructively and and/or remotely.

No wetting or corrosion was observed for specimens exposed below about $255^{\circ} \mathrm{C}$. Because the $\mathrm{Hg}$ did not chemically wet the low-temperature coupons, no deposition (mass transfer) was observed in the experiment. Much of the corrosion product transferred from the hot leg to the cold leg side was simply rejected from solution as the temperature dropped and it floated on the top of the $\mathrm{Hg}$. Subsequent analysis of this material after the loop was drained revealed primarily an amorphous $\mathrm{Hg}$-rich material with small amounts of crystalline $\mathrm{NiO}$ and $(\mathrm{Cr}, \mathrm{Fe})_{2} \mathrm{O}_{3}$. The presence of gallium in the "twin" TCL in the initial experiment did not increase wetting and in fact may have somewhat inhibited reaction of $\mathrm{Hg}$ with the stainless steel because little or no weight loss and no reaction layers were observed on the specimens from the loop with a Ga addition.

A series of TCL experiments was used to examine surface condition and thermomechanical treatment variables for annealed 316L/316LN stainless steels. In addition, other TCL experiments examined alternate alloys as well as other parameters such as $\mathrm{Hg}$ velocity and the feasibility of using ultrasonic energy as a tool to create fresh surfaces and chemical wetting in a TCL. Tables 1-7 provide a summary of the other TCLs and related experiments used to examine thermal gradient mass transfer in support of the compatibility program. The information is not intended to be all-inclusive but rather to indicate the scope of conditions examined and the overall results.

Table 1. General summary data for Loops 1 and 2.

\begin{tabular}{ll}
\hline \multicolumn{1}{c}{ Item } & \multicolumn{1}{c}{ Description } \\
\hline Nominal test coupons & Mill-annealed/surface ground $316 \mathrm{~L}$ stainless steel \\
Test coupon variations & -- \\
Loop construction materials & Mill-annealed 316L stainless steel \\
Special handling & Both loops steam cleaned after assembly \\
Loop working fluid & Pure $\mathrm{Hg}$ in one loop; $\mathrm{Hg}+1000 \mathrm{wppm} \mathrm{Ga}$ in the other loop \\
Hg velocity & $1.1 \mathrm{~m} / \mathrm{min}$ \\
Test duration & $5000 \mathrm{~h}$ \\
Temperature extremes & Max $305^{\circ} \mathrm{C}$ in hot leg; min $242^{\circ} \mathrm{C}$ in cold leg \\
Summary & See text in preceding paragraphs \\
\hline
\end{tabular}

Source: Reference 13. 
Table 2. General summary data for Loops 3 and 4.

\begin{tabular}{|c|c|}
\hline Item & Description \\
\hline Nominal test coupons & Mill-annealed/surface ground alloy 718 \\
\hline Test coupon variations & $\begin{array}{l}\text { - Coupons with one side polished } \\
\text { - Miniature tensile specimens }\end{array}$ \\
\hline Loop construction materials & Mill-annealed alloy 718 \\
\hline Special handling & Both loops steam cleaned after assembly \\
\hline Loop working fluid & Pure $\mathrm{Hg}$ in one loop; $\mathrm{Hg}+1000$ wppm $\mathrm{Ga}$ in the other loop \\
\hline Hg velocity & $1.1 \mathrm{~m} / \mathrm{min}$ \\
\hline Test Duration & $5000 \mathrm{~h}$ \\
\hline Temperature Extremes & Max $305^{\circ} \mathrm{C}$ in hot leg; $\min 242^{\circ} \mathrm{C}$ in cold leg \\
\hline Summary & $\begin{array}{l}\text { Alloy } 718 \text { considered as an alternate target window or } \\
\text { containment material. Due to relatively high solubility of } \mathrm{Ni} \text { in } \\
\mathrm{Hg}^{18} \text { and the observation that Ni was leached from stainless } \\
\text { steel in Hg service, } 13 \text { it was considered prudent to gather Hg } \\
\text { compatibility data for this Ni-base alloy. Coupons exhibited } \\
\text { negligible change in weight and no change in surface } \\
\text { roughness as a result of exposure. The Ga addition to Hg } \\
\text { had no effect on compatibility but contributed to a "scum" } \\
\text { formation on the Hg surface and on some coupons. }\end{array}$ \\
\hline
\end{tabular}

Source: Reference 10.

Table 3. General summary data for Loops 5 and 6.

\begin{tabular}{|c|c|}
\hline Item & Description \\
\hline Nominal test coupons & Mill-annealed/surface ground $316 \mathrm{~L}$ stainless steel \\
\hline Test coupon variations & $\begin{array}{ll}\text { - Polished (one side) } & \text { - Sensitization heat treatment } \\
\text { - Oxidized } & \text { - Miniature tensile specimens } \\
\text { - Gold coated (one side) } & \text { - Etched } \\
\text { - Welded } & \text { - Annealed } 316 \mathrm{LN} \\
\text { - Simulated radiation damage by ion bombardment }\end{array}$ \\
\hline Loop construction materials & $316 \mathrm{~L}$ stainless steel \\
\hline Special handling & One loop had $\mathrm{Hg}$ soak at $310^{\circ} \mathrm{C}$ prior to standard operation \\
\hline Loop working fluid & Pure $\mathrm{Hg}$ \\
\hline Hg velocity & $1.2 \mathrm{~m} / \mathrm{min}$ \\
\hline Test duration & $2000 \mathrm{~h}$ \\
\hline Temperature extremes & Max $306^{\circ} \mathrm{C}$ in hot leg; $\min 238^{\circ} \mathrm{C}$ in cold leg \\
\hline Summary & $\begin{array}{l}\text { The nominal coupons exhibited only isolated areas with porous } \\
\text { surface development along with Ni and Cr depletion }(\sim 5 \mu \mathrm{m} \text { in } \\
2000 \mathrm{~h}) \text {. The gold-coated specimens also revealed non-uniform } \\
\text { attack, but perhaps enhanced or accelerated chemical wetting } \\
\text { because the deepest penetration on the gold-coated side } \\
\text { approached } 15 \mu \mathrm{m} \text {. Although several treatments apparently } \\
\text { contributed to some post-test discoloration, none of the other } \\
\text { treatments generated a result significantly different than that of } \\
\text { the nominal coupons. The pretreatment in } \mathrm{Hg} \text { at } 310^{\circ} \mathrm{C} \text { had no } \\
\text { effect. }\end{array}$ \\
\hline
\end{tabular}

Source: Reference 14. 
Table 4. General summary data for Loops 7 and 8.

\begin{tabular}{|c|c|}
\hline Item & Description \\
\hline Nominal test coupons & Mill-annealed/surface ground $316 \mathrm{~L}$ stainless steel \\
\hline Test coupon variations & $\begin{array}{l}\text { - Gold coated (both sides) } \\
\text { - Polished (one side) } \\
\text { - Etched } \\
\text { - Sensitizing heat treatment }\end{array}$ \\
\hline Loop construction materials & 316L stainless steel \\
\hline Special handling & One loop steam cleaned after assembly \\
\hline Loop working fluid & Pure Hg \\
\hline Hg velocity & $1.2 \mathrm{~m} / \mathrm{min}$ in bulk of loop ; $\sim 5 \mathrm{~m} / \mathrm{min}$ in reduced section \\
\hline Test duration & $2000 \mathrm{~h}$ \\
\hline Temperature extremes & Max $304^{\circ} \mathrm{C}$ in hot leg; $\min 230^{\circ} \mathrm{C}$ in cold leg \\
\hline Summary & $\begin{array}{l}\text { The nominal coupons exhibited a modest weight loss but no } \\
\text { significant increase in surface roughness. Comparison of } \\
\text { coupons in the reduced section (venturi shape) near the top of } \\
\text { the hot leg with those outside the reduced section indicated no } \\
\text { change in coupon performance and thus no significant influence } \\
\text { of Hg velocity in the range examined. None of the specimen } \\
\text { treatments significantly altered coupon performance compared to } \\
\text { the nominal specimens. The sensitizing heat treatment } \\
\text { revealed, however, that the fabrication process used to make the } \\
\text { specimens for this experiment (electro-discharge machining) had } \\
\text { significantly carburized some areas of the specimens. }\end{array}$ \\
\hline
\end{tabular}

Source: Reference 16.

Table 5. General summary data for Loop 9.

\begin{tabular}{ll}
\hline \multicolumn{1}{c}{ Item } & Description \\
\hline Nominal test coupons & Mill-annealed/surface ground 316LN stainless steel \\
Test coupon variations & $\begin{array}{l}\text { - Gold coated (both sides) } \\
\text { - Polished (one side) } \\
\text { - Welded } \\
\text { - Oxidized }\end{array}$ \\
Loop construction materials & $316 \mathrm{~L}$ stainless steel \\
Special handling & None \\
Loop working fluid & Pure Hg \\
Hg velocity & $1 \mathrm{~m} / \mathrm{s}$ in test sections (electromagnetic pump) \\
Test duration & $1000 \mathrm{~h}$ (not continuous) \\
Temperature extremes & $\begin{array}{l}\text { Max 250 }{ }^{\circ} \mathrm{C} \text { in hot leg; min } 100^{\circ} \mathrm{C} \text { in cold leg } \\
\text { Summary }\end{array}$ \\
$\begin{array}{l}\text { The purpose of this loop experiment was to expose test coupons } \\
\text { to Hg at velocities similar to those expected in the SNS target } \\
\text { (rather than the modest velocities achieved in the TCLs). With } \\
\text { the possible exception of an erosion component that removed } \\
\text { heat treatment scale from oxidized specimens, no change in } \\
\text { compatibility for 316LN specimens was observed in this loop } \\
\text { compared to the TCLs at lower velocity. }\end{array}$ \\
\hline
\end{tabular}

Source: Reference 19. 
Table 6. General summary data for Loop 10.

\begin{tabular}{ll}
\hline \multicolumn{1}{c}{ Item } & \multicolumn{1}{c}{ Description } \\
\hline Nominal test coupons & Mill-annealed/surface ground 316L stainless steel \\
Test coupon variations & None \\
Loop construction materials & $316 \mathrm{~L}$ stainless steel \\
Special handling & None \\
Loop working fluid & Pure Hg \\
Hg velocity & Stagnant in bulk; local agitation via ultrasonic energy \\
Test duration & Series of 24-72 h exposures \\
Temperature extremes & Ambient \\
Summary & Bench-top exposures demonstrated that specimens of 316L \\
& $\begin{array}{l}\text { could be subjected to significant cavitation-erosion via pressure } \\
\text { pulses generated at locations remote to the specimen surface. } \\
\text { Attempts to use ultrasonic energy applied at the top of a TCL to } \\
\text { generate low temperature wetting in Hg proved unsuccessful. }\end{array}$ \\
\hline
\end{tabular}

Source: Reference 20.

Table 7. General summary data for Loop 11.

\begin{tabular}{|c|c|}
\hline Item & Description \\
\hline Nominal test coupons & Mill-annealed/surface ground $316 \mathrm{LN}$ stainless steel \\
\hline Test coupon variations & $\begin{array}{l}\text { - Bead-blasted surface } \\
\text { - } 50 \% \text { cold worked } \\
\text { - Kolsterized surface } \\
\text { - Nitronic } 60 \\
\text { - } 316 \text { L with kolsterized surface }\end{array}$ \\
\hline Loop Construction Materials & 316L stainless steel (previously used once) \\
\hline Special Handling & None \\
\hline Loop Working Fluid & pure $\mathrm{Hg}$ \\
\hline Hg velocity & $1.2-1.4 \mathrm{~m} / \mathrm{min}$ \\
\hline Test Duration & $2000 \mathrm{~h}$ \\
\hline Temperature Extremes & Max $307^{\circ} \mathrm{C}$ in hot leg; $\min 217^{\circ} \mathrm{C}$ in cold leg \\
\hline Summary & $\begin{array}{l}\text { There was no appreciable difference in coupon performance } \\
\text { between the nominal } 316 \mathrm{LN} \text { specimens and all the variants } \\
\text { thereof in this experiment, with all indicating very modest weight } \\
\text { change corresponding to negligible attack. In particular, the } \\
\text { kolsterized specimens performed identically to the nominal } \\
316 \mathrm{LN} \text { specimens. Weight changes associated with the } \\
\text { kolsterizing treatment itself indicate a process that is } \\
\text { reproducible but apparently very sensitive to base composition } \\
\text { and/or surface condition. }\end{array}$ \\
\hline
\end{tabular}

Source: Reference 17. 


\subsubsection{Bench-Top Compatibility Tests}

In addition to the series of thermal convection loop experiments, short-term benchtop exposures using beakers and hot-plates were performed on an assortment of materials exposed in static $\mathrm{Hg}$. Generally speaking, the purpose of these tests was to determine in an accelerated fashion - by raising the test temperature compared to expected exposure conditions - whether there might be significant compatibility concerns for a selected material in $\mathrm{Hg}$.

The general results of these exposures - documented informally in electronic mail messages to SNS staff - are consistent with expectations based on wetting tendency. That is, materials susceptible to wetting by $\mathrm{Hg}$ generally experience discoloration indicating a surface reaction, weight changes indicating general dissolution or pitting, or embrittlement, characterized by cracking or loss of ductility, even in relatively brief exposures. Over the course of the target materials R\&D program, a wide variety of elastomers in the form of o-rings, vibration pads, flexible tubing, and caulking materials were examined in $\mathrm{Hg}$. In addition, metals including $\mathrm{Fe}$ and $\mathrm{Fe}-$ base alloys such as stainless steels, Cr-plated steels, pure Ta, Co-base alloys, pure $\mathrm{Ni}$ and Ni-base alloys, pure $\mathrm{Cu}, \mathrm{Al}$ alloys, pure $\mathrm{Ag}$ and $\mathrm{Ag}$-containing solders, and pure $\mathrm{Au}$, were exposed to $\mathrm{Hg}$ in immersion tests. Although the brief exposures were not sufficiently extensive to justify sweeping conclusions, the trends can be summarized by:

\section{Pure Fe and Fe-base alloys:}

Compatible with $\mathrm{Hg}$; Fe has very low solubility and the air-formed oxide is stable and prevents wetting in $\mathrm{Hg}$; Fe alloyed with oxide-film formers such as $\mathrm{Cr}$ in stainless steels is very stable.

\section{Pure Ni:}

Inconsistent but generally poor compatibility with $\mathrm{Hg}$; solubility is relatively high; airformed passive film has only limited resistance and is subject to fail with spectacular pitting or locally high corrosion rates. ${ }^{21-23}$

Ni-base alloys:

Air-formed passive film is stable and prevents wetting/interaction.

\section{Co-base alloys:}

Air-formed passive film is stable and prevents wetting/interaction.

Cr (in plating):

Air-formed passive film is stable and prevents wetting/interaction. 
Pure $\mathrm{Ag}, \mathrm{Ag}$-solders, $\mathrm{Au}, \mathrm{Cu}$ :

All susceptible to rapid wetting and amalgamation with $\mathrm{Hg}$. Au and Ag-solders were used to improve wetting with specimens under some circumstances.

Al alloys:

Air-formed passive film is stable and can provide short-term resistance, but immersion in $\mathrm{Hg}$ can be expected to result in high dissolution rates, pitting, and cracking. ${ }^{24-28}$ Due to the proposed use of 6061-T6 aluminum in several balance-ofplant applications possibly subject to $\mathrm{Hg}$ vapor exposures, a more comprehensive evaluation of this alloy in $\mathrm{Hg}$ was undertaken. ${ }^{29}$ The results confirmed that Al alloys are is very susceptible to pitting and cracking when immersed in $\mathrm{Hg}$ but have considerable resistance to $\mathrm{Hg}$ vapor.

A summary of general compatibility with $\mathrm{Hg}$ for a variety of materials is reproduced in Fig. $5 .^{25}$ Overall, the results indicated there are consistent with those reported here. Caution is advised in using the data in Fig. 5, however, as it does not generally indicate specific exposure conditions or failure mode, and prototypic exposures are recommended to make specific determinations. 


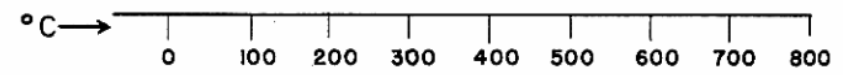

Ferrous Metals

\begin{tabular}{|c|c|c|}
\hline Eerrous Metals ( $\mathrm{Ti}$ and $\mathrm{Mg}$ in $\mathrm{Hg}$ ) & D & \\
\hline Low-C Steel & D & 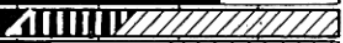 \\
\hline Low-C Steel +0.1 to $4 \mathrm{Al}$ & D & 1727171172 \\
\hline Low-C Steel $+<4 \mathrm{Cr}$ & D & Gilill \\
\hline $5 \mathrm{Cr}$ Steel & $\square$ & IIIIIIIIIIT \\
\hline Low-C Steel + $0.5 \mathrm{Mo}$ & [D] & Z1171772772 \\
\hline Low-C Steel + $20 \mathrm{Mo}$ & D & \\
\hline Low-C Steel + 1 to $3 \mathrm{Si}$ & DI & AIIIIII \\
\hline Low-C Steel +1 to $2 T i$ & [0 & AIIIIIIZIIZ \\
\hline Low-C Steel $+<2 \mathrm{Al}+<2 \mathrm{Cr}$ & D & IIIIIIITA \\
\hline Nitralloy $(1.23 \mathrm{Al}, 1.49 \mathrm{Cr})$ & D & 11IIIII \\
\hline Low-C Steel $+5.7 \mathrm{Cr}+1.2 \mathrm{Cu}$ & D & AIIIIIII \\
\hline Low-C Steel $+<4.5 \mathrm{Cr}+<4.5 \mathrm{Mo}$ & 0 & 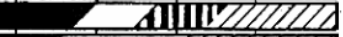 \\
\hline Low-C Steel $+5.7 \mathrm{Cr}+1.2 \mathrm{~W}$ & D. & $1717172 \pi$ \\
\hline Low-C Steel +15 to $20 \mathrm{Mo}+3 \mathrm{Si}$ & 0 & \\
\hline Low-C Steel $+8 \mathrm{Cr}+0.5 \mathrm{Al}+0.3 \mathrm{Mo}$ & D & \\
\hline Sicromo $5 \mathrm{~S}(5 \mathrm{Cr}, 0.5 \mathrm{Mo}, 1.5 \mathrm{Si})$ & $\mathrm{U}$ & АІІІІщШ \\
\hline Low $-C$ Steel $+5.5 \mathrm{Cr}+6.4 \mathrm{Mo}+1.4 \mathrm{Si}$ & 미 & \\
\hline Types 304 and 310 S. S. $(\mathrm{Cr}, \mathrm{Ni})$ & $D$ & ZIIZIIIA \\
\hline High $\mathrm{Ni}-\mathrm{Fe}$ and $\mathrm{Ni}-\mathrm{Cr}-\mathrm{Fe}$ Alloys & S & \\
\hline Ferritic Stainless Steels $(\mathrm{Cr})$ & [E] & \\
\hline
\end{tabular}

Nonferrous Metals

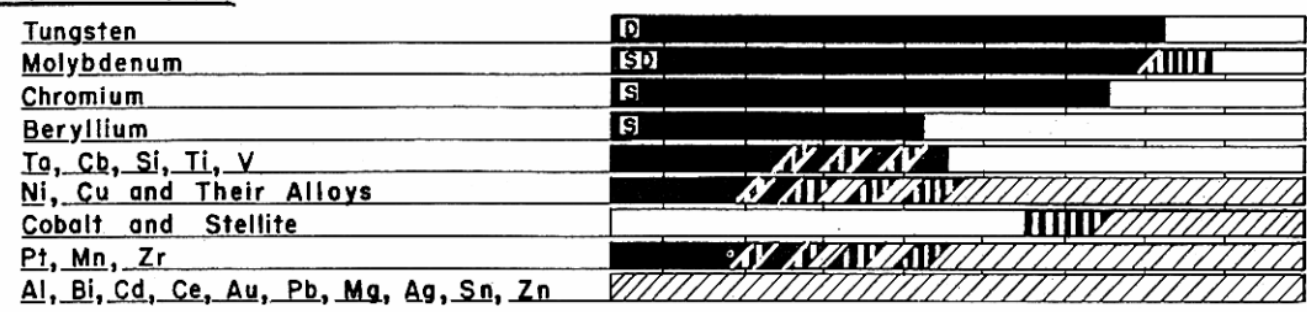

Non-Metals

Graphite (C)

Resistance Ratings:

(These ratings refer to liquidmetal resistance only- not to temperoture-dependent mechanical strength or metallurgical stability. See text for further discussion.)

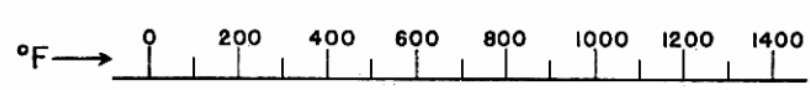

\footnotetext{
-GOOD-Consider for relatively long-time use. IIIII-LIMITED-Short-time use only. QIZZA-POOR- No structural possibilities. - UNKNOWN-Information inadequate.

- Dynamic mercury harp tests and industrial boiler tests.

D- Dynamic mercury harp tests.

s- Static mercury tests.
}

Fig. 6. Compatibility chart for liquid mercury with a variety of materials. Reproduced from Reference 25.

\subsection{LIQUID METAL EMBRITTLEMENT}

Another compatibility concern for structural materials exposed to $\mathrm{Hg}$ is a phenomenon termed liquid metal embrittlement (LME). In this form of degradation, the ductility of a stressed material is decreased - often dramatically in magnitude and very 
rapidly - by contact with a liquid metal. Experimental observations in a variety of liquid metals have indicated that this can occur through a range of processes - for example, grain boundary decohesion - but often there is little or no detectable chemical or structural modification prior to the formation and growth of brittle cracks. Most studies emphasize the requirement of a tensile stress and at least some degree of chemical wetting of the surface by the liquid metal. Although there are no "hard-and-fast" rules, LME tends to be most severe near the melting temperature of the liquid metal and decreases as the temperature is increased. Further, only very specific liquid metal solid metal couples seem susceptible to LME, and existing theory is inadequate to predict LME for specific cases.

Mercury is known to embrittle several metals, such as aluminum and its alloys, brass, nickel and some Ni-base alloys, $\mathrm{Ti}$, and $\mathrm{Zn}{ }^{30,31}$ In addition, at least one study has indicated evidence of LME by $\mathrm{Hg}$ of $304 \mathrm{~L}$ (but not $316 \mathrm{~L}$ ) stainless steel. ${ }^{32}$ To evaluate LME susceptibility for the selected target container material $316 \mathrm{~L} / 316 \mathrm{LN}$ and alloy 718 (alternate candidate), various mechanical tests were performed in $\mathrm{Hg}$ at room temperature and $100^{\circ} \mathrm{C}$.

\subsubsection{U-bends}

U-bends of 304L and 316 L stainless steel as well as several low alloy steels were immersed in pure $\mathrm{Hg}$ under room air for $72 \mathrm{~h}$ at each of ambient, 150,225 , and $275^{\circ} \mathrm{C}$. Aluminum specimens (6061-T6) were included in the exposures at ambient and $150^{\circ} \mathrm{C}$. Only the aluminum specimens suffered weight loss or cracking, which occurred most reproducibly at room temperature. The other materials exhibited no discoloration, weight change, or evidence of cracking. With the exception of testing at $275^{\circ} \mathrm{C}$, no evidence of wetting was observed on the stainless steel or steel specimens.

Subsequent testing focused on 304L stainless steel, because previous literature ${ }^{32}$ indicated that it was slightly more susceptible to wetting by $\mathrm{Hg}$ than $316 \mathrm{~L}$ and thus might present a more fruitful avenue to find interactions. A variety of surface treatments were incorporated, including gold plating, several acid cleaning/etching procedures, and abrasion under the $\mathrm{Hg}$ with scrub pads and engraving tools. In addition, some of the exposures included an addition of $\mathrm{Ga}$ to the $\mathrm{Hg}$ in an attempt to facilitate wetting. None of these conditions led to wetting at temperatures below $275^{\circ} \mathrm{C}$ and no weight change or cracking was observed at any temperature. 


\subsubsection{Tensile Tests}

A series of standard tensile tests was performed on sub-size specimens of $316 \mathrm{~L}$ stainless steel in air, $\mathrm{Hg}$, and $\mathrm{Hg}$ with up to 1000 wppm $\mathrm{Ga}$ at room temperature $\left(23^{\circ} \mathrm{C}\right)$. Figure 6 shows the fixture utilized to contain $\mathrm{Hg}$ around a specimen during a tensile test. Representative data for $316 \mathrm{~L}$ stainless steel in $\mathrm{Hg}$ at room temperature in several conditions (mill annealed, sensitization heat treatment, and as-welded) are shown in Fig. 7. The data reveal that, within the scatter of the measurement, the mechanical properties do not change as a function of environment. Further, the fracture surfaces resulting from each test were essentially $100 \%$ ductile/dimple in appearance, indicating no LME effects during the test. Very little wetting was noted for the $\mathrm{Hg}$ tests.

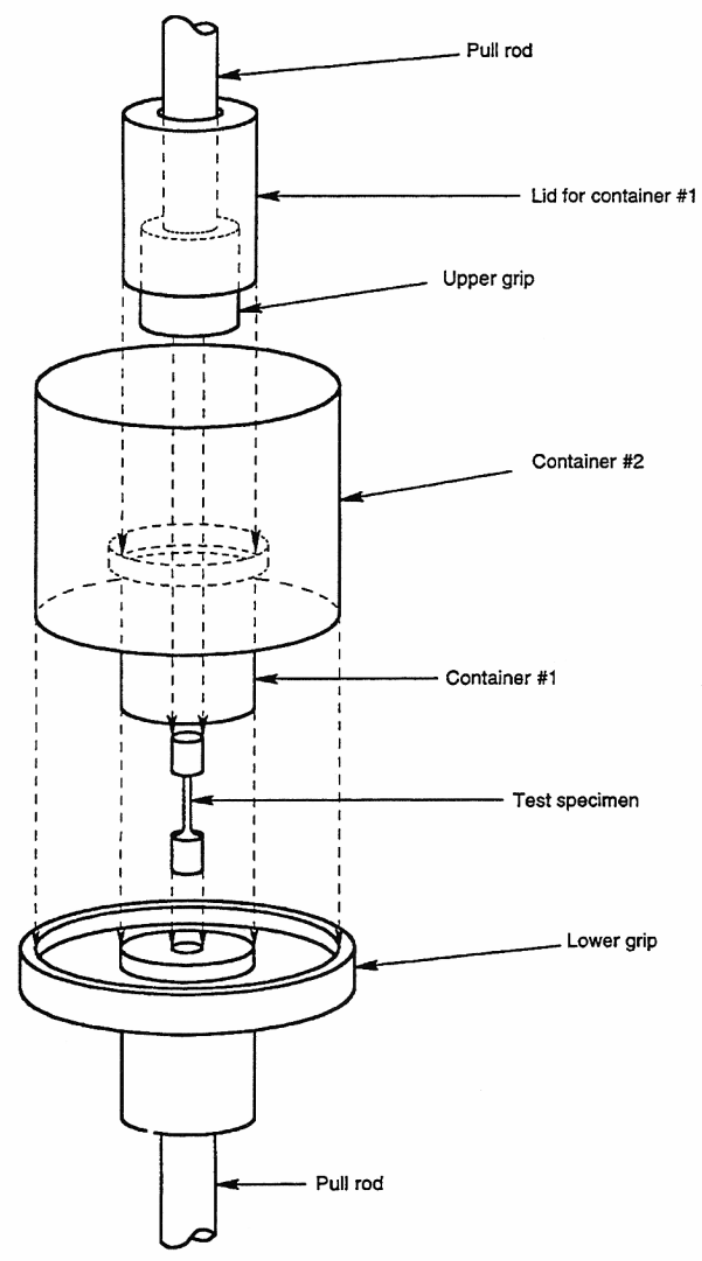

Fig. 7. Schematic of the apparatus for mechanical testing of specimens exposed to mercury. 


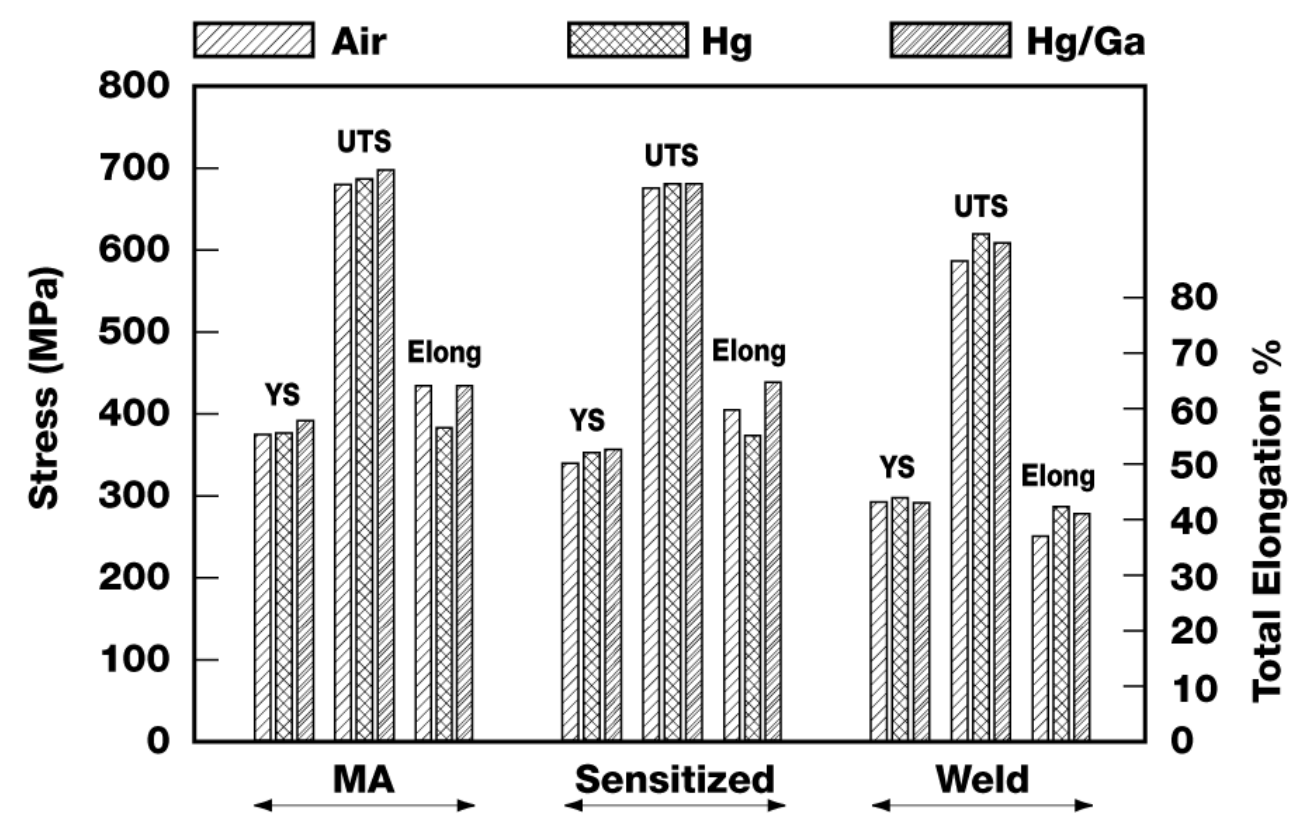

Fig. 8. Summary of mechanical test data for $316 \mathrm{~L}$ stainless steel in the mill-annealed (MA), sensitizing heat treatment $\left(2 \mathrm{~h}\right.$ at $\left.650^{\circ} \mathrm{C}\right)$, and as-welded conditions in three different environments at room temperature.

In general, mechanical properties can be sensitive to strain rate if the environment influences the specimen (via corrosion or LME, for example). In the case of potential LME effects, the strain rate of maximum sensitivity is not known but is often considered to result from a balance of straining rapidly enough to promote oxide fracture and crack initiation at many sites but sufficiently slowly to permit interaction of the liquid metal with the crack sites. To consider potential strain rate effects, the database for annealed $316 \mathrm{~L}$ stainless steel was expanded to include a range of strain rates from $10^{-8}$ to $10^{-2} \mathrm{~s}^{-1}$ for testing in $\mathrm{Hg}$ at room temperature. In all cases, the specimens revealed no change in mechanical properties, no discoloration, no weight change, and no brittle fracture features as a result of testing in $\mathrm{Hg}$ compared to air.

Liquid metal embrittlement is expected to be most aggressive at temperatures relatively close to the melting point of the liquid metal in question. In general, then, raising the temperature from 23 to $100^{\circ} \mathrm{C}$ would not be expected to produce a significant change from the previous results at $23^{\circ} \mathrm{C}$. However, $100^{\circ} \mathrm{C}$ is close to the expected operating temperature in the area of the target window, so a few tests at the prototypic temperature were included in the test matrix. Heating was accomplished by wrapping 
the $\mathrm{Hg}$ test container with heat tape. As expected, data collected at $100^{\circ} \mathrm{C}$ for $316 \mathrm{~L}$ revealed no influence of $\mathrm{Hg}$ compared to air.

A number of tests were repeated with additional effort to exacerbate wetting. For example, in several cases, the entire test container shown in Fig. 6 was ultrasonically agitated for up to $30 \mathrm{~min}$ in an attempt to improve wetting of the specimen prior to testing, but no effect of this treatment was observed. In addition, a few specimens had the gage section prepared by application of a layer of silver solder (97 Sn-3 Ag). Instantaneous wetting (low contact angle, chemical attack) and rapid amalgamation of the solder was observed in room temperature $\mathrm{Hg}$, but this had no effect on the tensile test results. In addition, one experiment included arresting the test progress at about $90 \%$ of the UTS for four days prior to completion of the test, and no effect was observed.

A set of tensile tests similar to that summarized in Fig. 7 was also performed for Alloy 718 in the mill-annealed and the as-welded conditions at room temperature. ${ }^{8,33}$ The mechanical test properties (UTS, YS, and elongation) revealed no influence of the $\mathrm{Hg}$ or $\mathrm{Hg}+\mathrm{Ga}$ environment compared to air. However, small areas of the fracture faces from the $\mathrm{Hg}$ and $\mathrm{Hg}+\mathrm{Ga}$ tests exhibited brittle features, including cracking. ${ }^{8,33}$

\subsubsection{Fatigue Tests}

In contrast with standard uniaxial tensile tests in which the specimens typically fail in a single fast fracture after plastic deformation (necking) has accommodated the maximum load, fatigue failure often generates one or more cracks at the specimen surface that propagate as the cyclic loading continues. If such a crack surface - free of oxide film - were wet by $\mathrm{Hg}$, the potential for LME would be enhanced.

At the outset of the compatibility project, 316LN specimens were subjected to fully reversed uniaxial fatigue loading at low frequency $(0.2-2.0 \mathrm{~Hz})$ at stresses well above the yield strength in air and in $\mathrm{Hg}$ at room temperature. ${ }^{34}$ Compared to specimens tested in air, specimens tested in $\mathrm{Hg}$ had reproducibly shorter fatigue lives by a factor of 2-3 and fracture faces exhibiting significant wetting by $\mathrm{Hg}$ and intergranular cracking. Representative photographs of fracture surfaces from tests in air and $\mathrm{Hg}$ are compared in Figs. 8 and 9. In air, the fracture features resulting from testing with a stress amplitude of $287 \mathrm{MPa}$ include classic fatigue striations across the entire surface with short, shallow cracks parallel to the striations in a few locations. In contrast, the fracture faces of the specimen tested identically in $\mathrm{Hg}$ exhibited brittle/cleavage features and extensive intergranular cracking. 
(a)

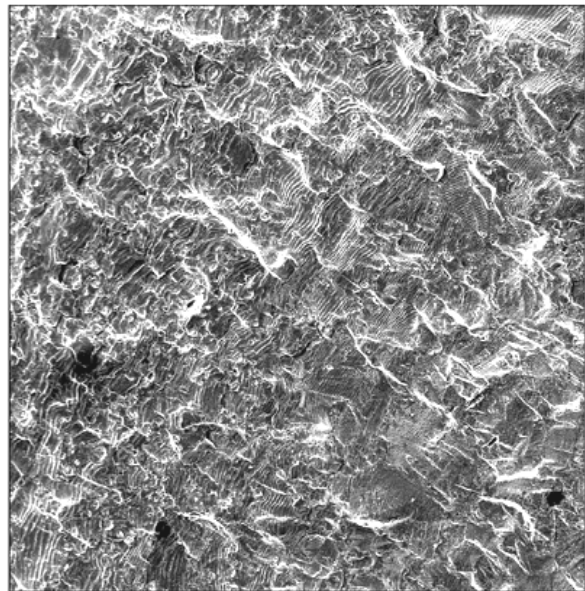

ET22500

$0.2 \mathrm{~mm}$ (b)

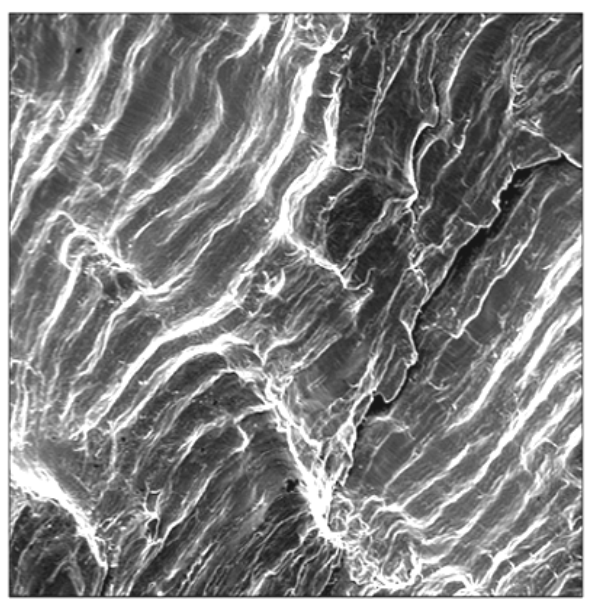

ET22502

$20 \mu \mathrm{m}$

Fig. 9. Fracture surface of $316 \mathrm{LN}$ fatigue specimen tested in air at room temperature (287 MPa, 4935 cycles to failure. Both photos are from the center of the specimen.

(a)

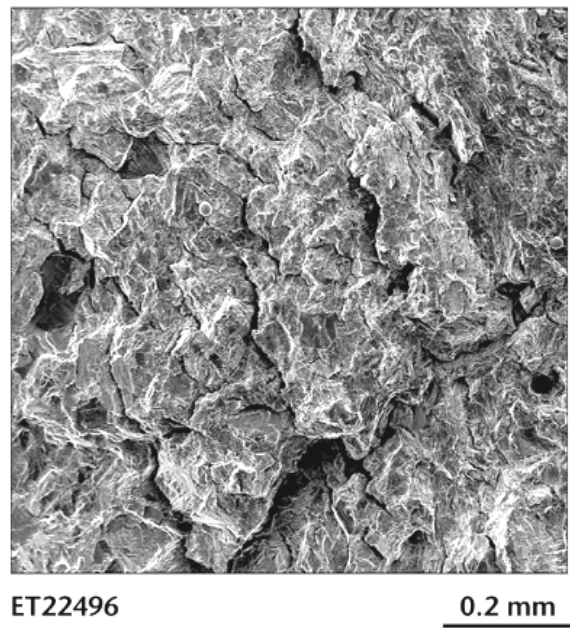

(b)

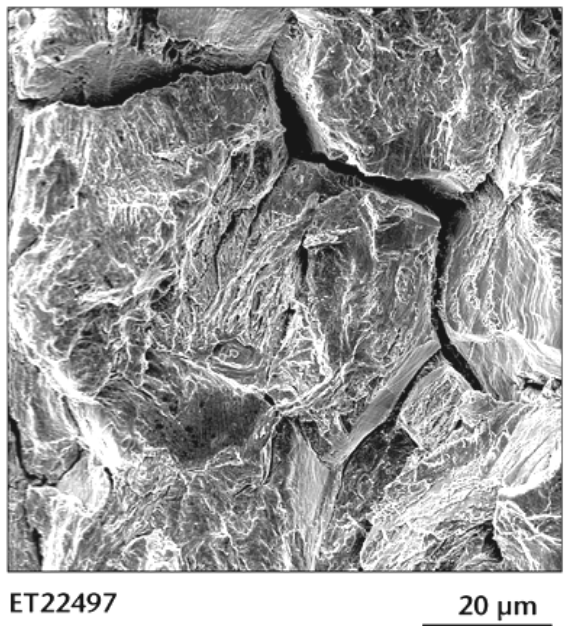

Fig. 10. Fracture surface of $316 \mathrm{LN}$ fatigue specimen tested in $\mathrm{Hg}$ at room temperature (287 MPa, 2572 cycles to failure. Both photos are from the center of the specimen.

At lower stresses approaching an apparent endurance limit, there was little or no difference observed in cycles to failure and fracture features for specimens tested in $\mathrm{Hg}$ and air. A more complete review of the fatigue data generated in support of the SNS target development is given in a separate summary report. ${ }^{35}$ It includes test data for wide ranges in cycle frequency, R-ratio, alloy starting condition, and a number of other 
variables. Typically, for stresses at or below the yield strength, no effect of $\mathrm{Hg}$ on fatigue life was observed.

\subsection{CAVITATION-EROSION}

The extreme local heating rate resulting from each pulse of the incident proton beam in the SNS is expected to give rise to a thermal-shock induced pressure wave. When the compression wave reaches a boundary, e.g., the target containment, the wave will be reflected back with a change of phase. The resulting rarefaction wave will expose the surrounding $\mathrm{Hg}$ to transient negative pressures. At a sufficient negative pressure routinely expected in the SNS target - microscopic bubbles are expected to form in the $\mathrm{Hg}^{36-38}$ When the bubbles collapse at or near the containment surface, some of the energy released - typically a jetting action of liquid at extreme velocity - can effectively erode the surface through a scrubbing action.

In addition to previously mentioned cavitation experiments, ${ }^{20}$ a series of tests using a vibratory horn ${ }^{39-42}$ were performed to quantitatively compare the relative cavitation-erosion resistance of a variety of $316 \mathrm{LN}$ stainless steel coupons in the annealed, cold-worked, and surface treated conditions with other materials in $\mathrm{Hg}$. Results from these tests were intended to complement other test results and provide some screening for various materials/treatments to support the limited in-beam testing at Los Alamos National Laboratory. ${ }^{43-45}$

In the vibratory horn tests, ${ }^{39-41}$ annealed $316 \mathrm{LN}$ proved susceptible to significant surface roughening and localized pitting compared to $50 \%$ cold-work $316 \mathrm{LN}$ or annealed $316 \mathrm{LN}$ that was kolsterized (a proprietary low temperature carburizing treatment). Representative weight loss data are shown in Fig. 10 which compares annealed and $50 \%$ cold-worked $316 \mathrm{LN}$. The results indicate that for these test conditions ( $25 \mu \mathrm{m}$ peakto-peak displacement amplitude, $20 \mathrm{kHz}$ frequency, $25^{\circ} \mathrm{C} \mathrm{Hg}$ ), the average wastage rate as exemplified by weight loss is 6-7 times greater for annealed material. 


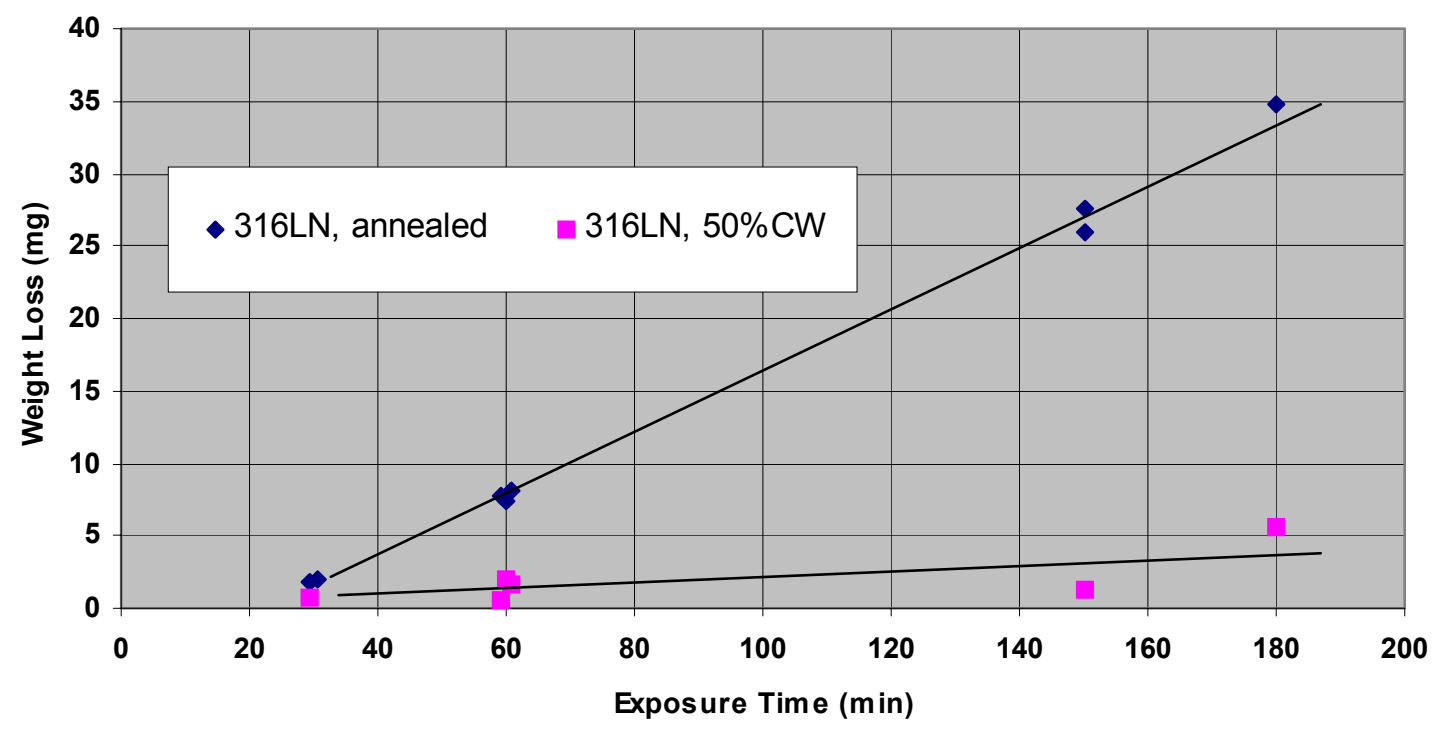

Fig. 11. Specimen weight loss vs. exposure time for vibratory horn testing (25 $\mathrm{\mu m}$ peak-to-peak displacement amplitude, $20 \mathrm{kHz}$ frequency, $25^{\circ} \mathrm{C}$ ) in $\mathrm{Hg}$. The trend lines are included for ease of presentation.

Microscopically, the difference in cavitation-erosion resistance between annealed and cold-worked $316 \mathrm{LN}$ is even more striking. Figures 11 and 12 show scanning electron micrographs of the surface of each type of specimen following sonication in $\mathrm{Hg}$. The annealed material was found to be quite susceptible to surface roughening and pitting, while the cold-worked specimen experienced only minor surface roughening and very limited, shallow pitting.

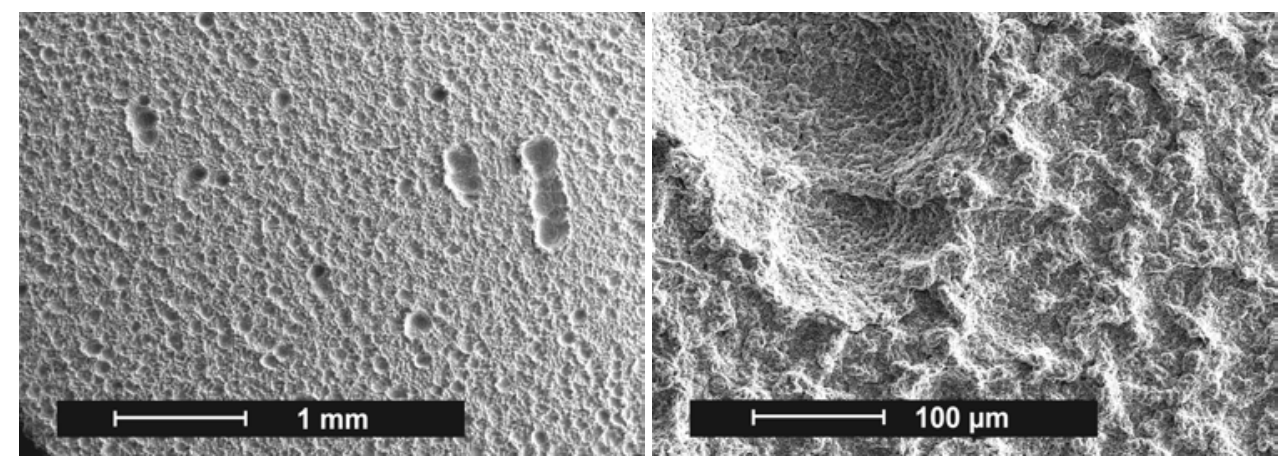

Fig. 12. Scanning electron micrographs of the surface of annealed 316LN after sonication ( $25 \mu \mathrm{m}$ peak-to-peak displacement amplitude, $20 \mathrm{kHz}$ frequency, $25^{\circ} \mathrm{C}$ ) for $150 \mathrm{~min}$ in $\mathrm{Hg}$. Photograph at right shows a higher magnification view of one of the large pits in the photograph at left. 


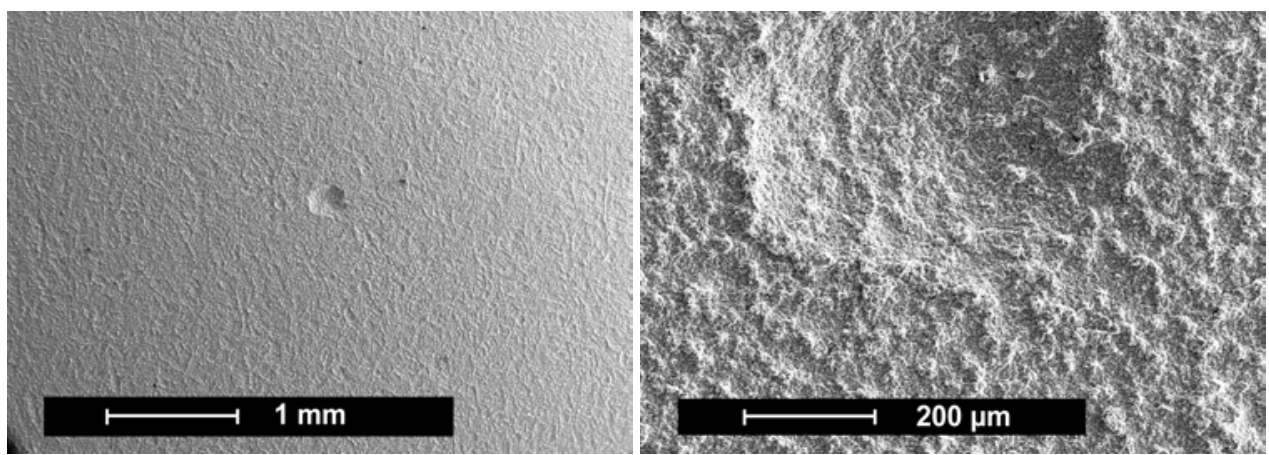

Fig. 13. Scanning electron micrograph of the surface of $50 \%$ coldworked $316 \mathrm{LN}$ after sonication ( $25 \mu \mathrm{m}$ peak-to-peak displacement amplitude, $20 \mathrm{kHz}$ frequency, $25^{\circ} \mathrm{C}$ ) for $180 \mathrm{~min}$ in $\mathrm{Hg}$. This photograph is not particularly representative in that the entire specimen surface exhibited only 2-3 such indications.

From the perspective of weight loss as a function of exposure time, annealed $316 \mathrm{LN}$ receiving the kolsterizing surface treatment performed nearly identically to the $50 \%$ cold-worked $316 \mathrm{LN}$. However, kolsterized specimens exhibited a different type of limited damage compared to the cold-worked specimens. Figure 13 contains a representative example of this observation, which shows a somewhat linear, crack-like indication on the kolsterized surface.

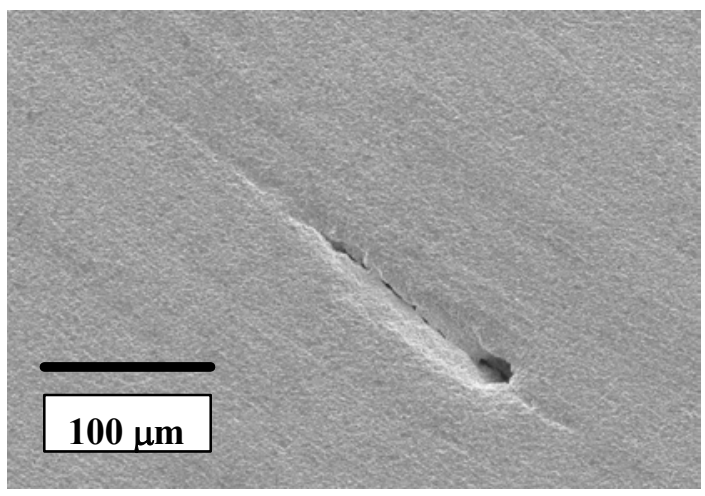

Fig. 14. Annealed 316LN specimen receiving kolsterizing treatment and exposed to sonication ( $25 \mu \mathrm{m}$ peak-topeak displacement amplitude, $20 \mathrm{kHz}$ frequency, $25^{\circ} \mathrm{C}$ ) for $60 \mathrm{~min}$ in $\mathrm{Hg}$. 
Other potentially cavitation resistant materials (Nitronic 60, Inconel 718, Stellite 3) did not perform significantly better than cold-worked or kolsterized $316 \mathrm{LN}$. Other surface treatments for $316 \mathrm{LN}$ (laser treatment to form diamond-like layers, CrN coating, metallic glass coating) provided little or no protection for the substrate.

A consistent observation in the vibratory horn tests was that the specimen buttons were rapidly and tenaciously wetted by $\mathrm{Hg}$ even after short (1-2 minute) sonication exposures. However, upon termination of the test and exposure of the button to room air, the Hg gradually "beaded" on the surface until little evidence of wetting remained after a period of 1-2 h. Wetting was probably encouraged by the erosive action of the cavitation process cleaning the button surface of oxide, but the surface oxide is quick to reform when sonication ceases. 



\section{CONCLUSIONS}

None of the $\mathrm{Hg}$ compatibility experiments reported here included simultaneous exposure to irradiation and flowing $\mathrm{Hg}$ during testing. While that is a potential shortcoming of the results presented, the cost of such an evaluation was deemed prohibitive at the outset of the program and the compatibility tests were largely limited to studies in the absence of irradiation effects. However, some pains to facilitate wetting as might be found in the actual SNS target were included in the test protocol.

In summary of the various flow loop experiments, a wide range of surface conditions and heat treatments for 316L/316LN stainless steel and a few alternate alloys were evaluated in $\mathrm{Hg}$ at temperatures well in excess of those expected in actual SNS service to exacerbate wetting. The data collected indicate that, with the possible exception of gold-plating to accelerate/enhance wetting, none of the treatments/conditions had an appreciable effect on compatibility with $\mathrm{Hg}$. On specimens without gold-plating, the greatest extent of attack - about 9-10 $\mu \mathrm{m}$ of relatively uniform penetration - was observed on annealed $316 \mathrm{~L}$ specimens exposed to $\mathrm{Hg}$ at $305^{\circ} \mathrm{C}$ for $5000 \mathrm{~h}$. The penetration was manifest by the appearance of a porous surface layer substantially depleted of $\mathrm{Ni}$ and $\mathrm{Cr}$ and transformed to ferrite. A single gold-coated specimen revealed non-uniform attack to a maximum depth of about $15 \mu \mathrm{m}$ in $2000 \mathrm{~h}$ at about $290^{\circ} \mathrm{C}$, but other gold-coated coupons in the same experiment revealed much less interaction. Specimens exposed at lower temperatures or for shorter times exhibited considerably less interaction in magnitude and uniformity, and coupons exposed below about $250^{\circ} \mathrm{C}$ revealed no measurable interaction at all. Other practical implications of the loop data are that the presence of a reaction layer due to $\mathrm{Ni}$ and $\mathrm{Cr}$ leaching can be detected non-destructively with magnetic measurements and that $\mathrm{Hg}$ velocity does not appear to have a significant influence on compatibility of 316L/316LN. Unless significant wetting occurs under SNS conditions, it is not believed that mass transfer will play a significant role in the SNS mercury target during anticipated service lifetimes.

Mechanical tests to examine the potential for liquid metal embrittlement in 316L included standard tensile tests of annealed, as-welded, and sensitized material examined in a range of strain rates in $\mathrm{Hg}$ at 23 and $100^{\circ} \mathrm{C}$. A limited number of tests also included various specialized procedures to encourage wetting, such as ultrasonic treatment of the test container and coating specimen gage sections with silver solder. For all conditions with $316 \mathrm{~L}$, wetting of the surface by $\mathrm{Hg}$ was problematic and no indication of embrittlement was observed for any of the conditions examined compared to 
identical tests in air. Similarly, alloy 718 showed no significant change in mechanical test properties, but specimen fracture faces revealed traces of brittle behavior, particularly at the edges of the specimen.

In preliminary fatigue testing of $316 \mathrm{LN}$ in $\mathrm{Hg}$, relatively high loads above the yield strength of the material generated lower cycles to failure and indications of brittle failure features compared with identical tests in air. At lower fatigue loads, $\mathrm{Hg}$ had much less influence on fatigue life and fracture features. A summary of more complete fatigue test results was presented in a separate document.

Annealed $316 \mathrm{LN}$ is somewhat susceptible to cavitation-erosion damage. Screening tests using the vibratory horn indicated that annealed $316 \mathrm{LN}$ suffers general surface roughening with concomitant weight loss and localized pitting as a result of exposure to sonication conditions in $\mathrm{Hg}$. Considerable improvement was realized with a kolsterizing surface treatment or $50 \%$ cold-working, as each of these decreased the mass loss rate by a factor of 6-7 and decreased the depth/frequency of pitting. Both the kolsterizing treatment and cold-working had no adverse effect on coupon performance in the thermal convection loop tests. 


\section{ACKNOWLEDGMENTS}

A number of individuals have contributed significantly to the information in this document and specific contributions are acknowledged in the many reports cited herein bearing the author's name. Of particular note, E. T. Manneschmidt provided able technician support throughout the research effort. H. F. Longmire provided metallography services and L. R. Walker and E. A. Kenik provided scanning electron microscope and microprobe support. J. R. DiStefano provided many helpful discussions throughout the course of the program and reviewed this manuscript. R. B. Ogle and S. N. Lewis provided Industrial Hygiene services. F. C. Stooksbury, K. A. Choudhury, and S. A. Shugart helped prepare the manuscript and graphics. The research was sponsored by the Spallation Neutron Source. 



\section{REFERENCES}

1. L. K. Mansur and H. Ullmaier, compiled Proceedings of the International Workshop on Spallation Materials Technology, CONF-9604151, Oak Ridge, TN, April 23-25, 1996.

2. L. K. Mansur, "Materials R\&D for the Spallation Neutron Source," Proceedings of the $5^{\text {th }}$ International Workshop on Spallation Materials Technology, IWSMT-5, Charleston, SC, May 19-24, 2002, special addition of J. Nucl. Mater., to be published in 2003.

3. L. K. Mansur, T. A. Gabriel, J. R. Haines, and D. C. Lousteau, "R\&D for the Spallation Neutron Source Mercury Target,” J. Nucl. Mater. 296 (2001) 1-16.

4. D. K. Felde, et al., Mercury Thermal Hydraulic Loop (MTHL) - Final Report, Spallation Neutron Source Report SNS/TSR-209, 101050100-TR0004-R00, December 2000.

5. D. R. Lide, Jr., ed., Journal of Physical and Chemical Reference Data, Vol. 11, Supplement No. 2, 1982, published by the Amer. Chem. Soc. and the Amer. Inst. of Physics for the National Bureau of Standards.

6. M. C. Wilkinson, "The Surface Properties of Mercury," Chemical Reviews, Vol. 72, No. 6, pp. 575-625 (December 1972).

7. H. N. Hackett, "Mercury for the Generation of Light, Heat, and Power," Transactions of the ASME, pp. 647-66 (1942).

8. J. R. DiStefano, S. J. Pawel, and E. T. Manneschmidt, Materials Compatibility Studies for the Spallation Neutron Source, ORNL/TM-13675, September 1998.

9. S. J. Pawel, "Results of Hg Wetting Experiments," Internal Correspondence (electronic mail) to L. K. Mansur and Distribution, January 30, 1998.

10. S. J. Pawel, J. R. DiStefano, and E. T. Manneschmidt, Corrosion of Alloy 718 in a Mercury Thermal Convection Loop, ORNL/TM-1999/323, December 1999.

11. L. F. Epstein, "Static and Dynamic Corrosion and Mass Transfer in Liquid Metal Systems," in Liquid Metals Technology - Part I, F. J. Antwerpen, ed., Chemical Engineering Progress Symposium Series, No. 20, Vol. 53, p. 67 (1957).

12. J. R. DiStefano, A Review of the Compatibility of Containment Materials with Potential Liquid Metal Targets, ORNL/TM-13056, August 1995.

13. S. J. Pawel, J. R. DiStefano, and E. T. Manneschmidt, Corrosion of Type 316L Stainless Steel in a Mercury Thermal Convection Loop, ORNL/TM-13754, April 1999.

14. S. J. Pawel, J. R. DiStefano, and E. T. Manneschmidt, Effect of Surface Condition and Heat Treatment on Corrosion of Type 316L Stainless Steel in a Mercury Thermal Convection Loop, ORNL/TM-2000/195, July 2000. 
15. S. J. Pawel, J. R. DiStefano, and E. T. Manneschmidt, "Thermal Gradient Mass Transfer of Type 316L Stainless Steel and Alloy 718 in Flowing Mercury," J. Nucl. Mater., 296 (2001) 210-218.

16. S. J. Pawel, J. R. DiStefano, and E. T. Manneschmidt, "Effect of Mercury Velocity on Corrosion of Type 316L Stainless Steel in a Thermal Convection Loop," ORNL/TM-2001/18, February 2001.

17. S. J. Pawel, J. R. DiStefano, and E. T. Manneschmidt, Examination of Compatibility of Cavitation-Resistant Modifications to Type 316LN Stainless Steel in a Mercury Thermal Convection Loop, ORNL/TM-2002/169, September 2002.

18. J. R. Weeks, "Liquidus Curves and Corrosion of $\mathrm{Fe}, \mathrm{Cr}, \mathrm{Ni}, \mathrm{Co}, \mathrm{V}, \mathrm{Cb}, \mathrm{Ta}, \mathrm{Ti}, \mathrm{Zr}$ in 500-750C Mercury," Corrosion, Vol. 23, No. 4, pp.98-106 (1967).

19. S. J. Pawel and E. T. Manneschmidt, "Influence of Mercury Velocity on Compatibility with Type 316L/316LN Stainless Steel in a Flow Loop," Proceedings of the $5^{\text {th }}$ International Workshop on Spallation Materials Technology, IWSMT-5, Charleston, SC, May 19-24, 2002, special addition of J. Nucl. Mater., to be published in 2003.

20. S. J. Pawel, E. T. Manneschmidt, R. P. Taleyarkhan, S. H. Kim, and J. R. DiStefano, Cavitation as a Mechanism to Enhance Wetting in a Mercury Thermal Convection Loop, ORNL/TM-2001/086, May 2001.

21. S. J. Pawel, "Coupon Exposures - Ni and Stellite," Internal Correspondence (electronic mail) to D. C. Lousteau, November 29, 2001.

22. S. J. Pawel, "Additional Compatibility Testing in Hg," Internal Correspondence (electronic mail) to D. C. Lousteau, December 19, 2001.

23. S. J. Pawel, "More Test Results," Internal Correspondence (electronic mail) to D. C. Lousteau, January 3, 2002.

24. R. D. Kane, D. Wu, and S. M. Wilhelm, in: R. D. Kane (Ed.), Slow Strain Rate Testing for the Evaluation of Environmentally Induced Cracking, American Society for Testing and Materials, Philadelphia, 1993, p.181.

25. R. N. Lyon (Ed), Liquid Metals Handbook, NAVEXOS P-733 (Rev.), Atomic Energy Commission, Washington, DC. 1952.

26. D. R. Mclntyre, J. J. English, and G. Kobrin, "Mercury Attack of Ethylene Plant Alloys," Paper 106, CORROSION ‘89, New Orleans, 1989.

27. J. J. Krupowicz, "Slow Strain Rate Fracture Characteristics of Steel and Aluminum Alloys Tested in Mercury Environments," J. Eng. Mater. Technol., 111 (1989) 229.

28. S. M. Wilhelm, R. D. Kane, and A. McArthur, Proc. $73^{\text {rd }}$ Gas Processors Assoc., New Orleans, March 1994, p. 807. 
29. S. J. Pawel and E. T. Manneschmidt, "Corrosion of Type 6061-T6 Aluminum in Mercury and Mercury Vapor," Proceedings of the $5^{\text {th }}$ International Workshop on Spallation Materials Technology, IWSMT-5, Charleston, SC, May 19-24, 2002, special addition of $J$. Nucl. Mater., to be published in 2003.

30. C. E. Price and J. K. Good, "The Tensile Fracture Characteristics of Nickel, Monel, and Selected Superalloys Broken in Liquid Mercury," ASME Journal of Engineering Materials and Technology, Vol. 106, p. 184 (1984).

31. M. G. Nicholas, "A Survey of Literature on Liquid Metal Embrittlement of Metals and Alloys," in Embrittlement by Solid and Liquid Metals, M. H. Kamdar, ed., Proceedings of the Metallurgical Society of AIME, Fall Meeting of the Metallurgical Society in St. Louis, MO, October 1982, pp. 27-50.

32. J. J. Krupowicz, "Effect of Heat Treatment on Liquid Metal-Induced Cracking of Austenitic Alloys," in Slow Strain Rate Testing for the Evaluation of Environmentally Induced Cracking: Research and Engineering Applications, ASTM STP 1210, R. D. Kane, ed., ASTM, Philadelphia, 1993, pp.193-201.

33. J. R. DiStefano, S. J. Pawel, and E. T. Manneschmidt, "Materials Compatibility Studies for the Spallation Neutron Source," Proceedings of the $2^{\text {nd }}$ International Topical Meeting on Nuclear Applications of Accelerator Technology (AccApp'98), Gatlinburg, TN, September 20-23, 1998, pp. 382-387.

34. S. J. Pawel, et al., Screening Test Results of Fatigue Properties of Type 316LN Stainless Steel in Mercury, ORNL/TM-13759, March 1999.

35. J. P. Strizak, H. Tian, P. K. Liaw, and L. K. Mansur, Fatigue Properties of Type 316LN Stainless Steel in Air and Mercury," SNS-101060200-TD0001-R00, October 2002.

36. R. P. Taleyarkhan, et al., "Experimental Determination of Cavitation Thresholds in Liquid Water and Mercury," Proceedings of the $2^{\text {nd }}$ International Topical Meeting on Nuclear Applications of Accelerator Technology (AccApp'98), Gatlinburg, TN, September 20-23, 1998, pp. 650-657.

37. F. Moraga and R. P. Taleyarkhan, "Static and Transient Cavitation Threshold Measurements in Mercury," Proceedings of the $3^{\text {rd }}$ International Topical Meeting on Nuclear Applications of Accelerator Technology (AccApp'99), Long Beach, CA, November 14-18, 1999, pp.301-307.

38. R. P. Taleyarkhan, et al., "Thermal Shock Assessments for the SNS Target System," Proceedings of the International Topical Meeting on Advanced Reactor Safety (ARS'97), Orlando, FL, June 1-5, 1997, p.379.

39. S. J. Pawel and E. T. Manneschmidt, "Preliminary Evaluation of Cavitation Resistance of Type 316LN Stainless Steel in Mercury Using a Vibratory Horn," Proceedings of the $5^{\text {th }}$ International Workshop on Spallation Materials Technology, IWSMT-5, Charleston, SC, May 19-24, 2002, special addition of J. Nucl. Mater., to be published in 2003. 
40. S. J. Pawel, "Cavitation Tests on Kolsterized Material," Internal Correspondence (electronic mail) to L. K. Mansur, June 19, 2002.

41. S. J. Pawel, "Cavitation Tests on Kolsterized Material - SEM Photos," Internal Correspondence (electronic mail) to L. K. Mansur, July 9, 2002.

42. "Standard Test Method for Cavitation Erosion Using Vibratory Apparatus," ASTM G32-98, American Society for Testing and Materials," Philadelphia, PA (1998).

43. J. R. Haines, et. al., Summary of Mercury Target Pitting Issue, Spallation Neutron Source Technical Report SNS-101060100-TR0004-R00, April 2002.

44. B. W. Riemer, et al., "SNS Target Tests at the LANSCE-WNR in 2001," Proceedings of the $5^{\text {th }}$ International Workshop on Spallation Materials Technology, IWSMT-5, Charleston, SC, May 19-24, 2002, special addition of J. Nucl. Mater., to be published in 2003.

45. J. D. Hunn, et. al., "Cavitation Damage in a Mercury Filled Container Irradiated by $800 \mathrm{MeV}$ Proton Pulses," Proceedings of the $5^{\text {th }}$ International Workshop on Spallation Materials Technology, IWSMT-5, Charleston, SC, May 19-24, 2002, special addition of J. Nucl. Mater., to be published in 2003. 


\section{INTERNAL DISTRIBUTION}

1. R. R. Allen

2. R. E. Battle

3. E. E. Bloom

4. K. K. Chipley

5. J. E. Cleaves

6. J. W. Cobb

7. H. H. Cromwell

8. J.R. DiStefano

9. D. A. Everitt

10. K. Farrell

11. T. A. Gabriel

12. J. R. Haines

13. L. L. Horton

14. J. D. Hunn

15. L. L. Jacobs

16. D. R. Johnson

17. J. O. Johnson

18. R. D. Lawson

19. D. C. Lousteau

20. A. T. Lucas

21. E. T. Manneschmidt
22. L. K. Mansur

23. T. E. Mason

24. T. J. McManamy

25. G. E. Michaels

26-30. S. J. Pawel

31. M. J. Rennich

32. B. W. Riemer

33. S. L. Schrock

34. P. T. Spampinato

35. C. N. Strawbridge

36. J. P. Strizak

37. P. F. Tortorelli

38. J. H. Whealton

39. D. K. Wilfert

40. G. L. Yoder

41-42. Central Research Library

43. Document Reference Section

44-45. ORNL Laboratory Records-RC

46. Office of Scientific \& Technical Information

\section{EXTERNAL DISTRIBUTION}

47. G. Bauer, Forschungszentrum Juelich, ESS Building 09.1, Leo-Brandt-Strasse, Juelich 52428 Germany.

48. J. M. Carpenter, Argonne National Laboratory, 9700 South Cass Ave, Bldg. 360, IPNS Division, Argonne, IL 60439.

49. A. Jason, Los Alamos National Laboratory, P.O. Box 1663, H817 LANSCE-1, Los Alamos, NM 87545. 
50. P. Liaw, University of Tennessee, Department of Materials Science and Engineering, 427-B Dougherty Engineering Building, Knoxville, TN 37996-2200.

51. M. Todosow, Brookhaven National Laboratory, P.O. Box 5000, Bldg 475B, Upton, NY 11973.

52. M. Wechsler, 106 Hunter Hill Place, Chapel Hill, NC 27514-9128.

53. W. Weng, Brookhaven National Laboratory, P.O. Box 5000, Bldg. 911B, Upton, NY 11973. 